\title{
Physiological responses to fluctuating thermal and hydration regimes in the chill susceptible insect, Thaumatotibia leucotreta
}

\author{
Leigh Boardman $^{\mathrm{a}, *}$, Jesper G. Sørensen ${ }^{\mathrm{b}}$, John S. Terblanche ${ }^{\mathrm{a}}$ \\ ${ }^{a}$ Centre for Invasion Biology, Department of Conservation Ecology and Entomology, Faculty of AgriSciences, Stellenbosch University, Private Bag X1, Matieland 7602, South Africa \\ ${ }^{\mathrm{b}}$ Department of Bioscience, Aarhus University, Vejlsøvej 25, P.O. Box 314, DK-8600 Silkeborg, Denmark
}

\section{A R T I C L E I N F O}

\section{Article history:}

Received 19 March 2013

Received in revised form 9 May 2013

Accepted 10 May 2013

Available online 15 May 2013

\section{Keywords:}

Repeated stress

HSP70

Metabolic rate

Repeated dehydration

\begin{abstract}
A B S T R A C T
Fluctuating thermal regimes (FTR), consisting of cycles between stressful low and benign temperatures, are known to improve survival and fecundity in a variety of insects. By contrast, fluctuating hydration regimes (FHR) consisting of cycles between dehydrating and benign conditions have been less comprehensively researched. Hypothetically, either repeated stress accumulates damage and reduces survival, or the recovery periods may act as a protective mechanism by allowing low temperature- or dehydration-induced damage to be repaired. Using false codling moth (Thaumatotibia leucotreta) larvae, we investigated whether FTR and FHR resulted in protection, or accumulated damage, at the cellular and wholeorganism levels. Time- and age-matched controls were used to verify that the effects were due to the fluctuating stressors and not age- or time-dependent responses. Results showed that larval body water-(BWC) and lipid content (BLC) remained unchanged in response to FTR. Importantly though, FTR are protective when compared to constant low temperature exposures, potentially due to an increase in heat shock protein 70 (HSP70). However, larvae may suffer long-term fitness consequences compared to constant benign exposures. Results for FHR appear equivocal when compared to constant controls, due to high survival rates for all experiments, although the physiological responses to FHR included a decrease in larval BWC and BLC, a decrease in cuticular water loss rates, and a depletion of HSP70 during the final dehydration cycle. In conclusion, it appears that fluctuating stressors are protective in T. leucotreta when compared to constant stress conditions, likely through regulation of whole-animal metabolic rate and HSP70, although other mechanisms (e.g. ion homeostasis) are also implicated.
\end{abstract}

(c) 2013 Elsevier Ltd. All rights reserved.

\section{Introduction}

Temperature and dehydration are two abiotic stressors commonly encountered by a wide range of insects in terrestrial environments. The duration of exposure to the stress and whether the stress is a single event versus a repeated exposure can both play an interactive role in determining which physiological responses are induced and whether an insect is able to survive exposure to temperature and/or dehydration extremes. In insects, low temperature tolerance and dehydration tolerance are thought to be closely linked as a result of (i) overlapping adaptations in haemolymph solutes, protective structures and habitat selection (Ring and Danks, 1994), (ii) similar cellular and molecular responses to these stressors (reviewed in Chown and Terblanche, 2007; Chown et al., 2011) and (iii) the close ties of both traits to species distributions (e.g. Kellermann et al., 2012). Ultimately, when physiological thresholds are overwhelmed and the scope for phenotypic plasticity has been exhausted (or does not exist) exposure to either low

\footnotetext{
* Corresponding author. Tel.: +27 21808 4671; fax: +27 218082546.

E-mail address: lboardman@sun.ac.za (L. Boardman).
}

temperature or dehydrating conditions can lead to mortality (e.g. Chown and Terblanche, 2007; Whitman and Agrawal, 2009).

The physiological effects of repeated or fluctuating stressors under field conditions are difficult to predict as most studies are performed in controlled laboratory settings (Worner, 1992; Niehaus et al., 2012). Given the integrated nature of responses to fluctuating, repeated stress, together with potentially non-linear interactions between time and temperature (Ruel and Ayres, 1999), inferring survival based on well-determined responses to immediate single exposures is considered to be challenging (discussed in Marshall and Sinclair, 2010). Exposure to longer-term low temperatures broken by repeated short benign temperature periods (i.e. fluctuating thermal regimes, FTR), or exposure to dehydrating conditions broken by periods of recovery (fluctuating hydration regimes, FHR), theoretically can result in one of two effects: either the effects of repeated stress accumulate, lowering fitness and reducing survival, or recovery periods allow for repair of damage and thus enhance survival. When compared to constant low temperature exposures, FTR reduces exposure time to potentially injurious low temperatures. Thus, it may be generally expected that FTR would be less fatal owing to the summed duration of stress 
Table 1

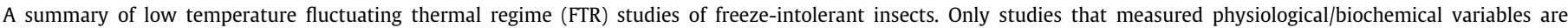
included, while freeze tolerant species or studies that investigated only developmental rates or survival/emergence are excluded.

\begin{tabular}{|c|c|c|c|c|c|c|c|}
\hline Order & Family & Species & $\begin{array}{l}\text { Life- } \\
\text { stage }^{a}\end{array}$ & FTR & $\begin{array}{l}\text { Variables } \\
\text { measured }^{\text {b }}\end{array}$ & $\begin{array}{l}\text { Outcome - all for FTR relative to } \\
\text { constant ctrl (unless stated) }\end{array}$ & Reference \\
\hline \multirow[t]{4}{*}{ Coleoptera } & Tenebrionidae & $\begin{array}{l}\text { Alphitobius } \\
\text { diaperinus }\end{array}$ & A & $4^{\circ} \mathrm{C}(22 \mathrm{~h})$ to $25^{\circ} \mathrm{C}(2 \mathrm{~h})$ & $\begin{array}{l}\text { [ions], } \\
\text { osmolality, } \\
\mathrm{H}_{2} \mathrm{O}, \mathrm{CT} \text {, Surv }\end{array}$ & $\begin{array}{l}\text { Slower chill injury, longer survival, } \\
\text { haemolymph }[\mathrm{K}+] \text { lower }\end{array}$ & $\begin{array}{l}\text { Koštál et al. } \\
\text { (2007) }\end{array}$ \\
\hline & Tenebrionidae & $\begin{array}{l}\text { Alphitobius } \\
\text { diaperinus }\end{array}$ & A & $\begin{array}{l}20^{\circ} \mathrm{C}(12 \mathrm{~h}) \text { with } 0{ }^{\circ} \mathrm{C}(12 \mathrm{~h}) \\
\text { daily }\end{array}$ & $\begin{array}{l}\text { Metabolites, } \\
\text { FFA, cryo }\end{array}$ & $\begin{array}{l}\uparrow \text { survival, lowered FAA pool, sugars } \\
\text { involved }\end{array}$ & $\begin{array}{l}\text { Lalouette } \\
\text { et al. (2007) }\end{array}$ \\
\hline & Tenebrionidae & $\begin{array}{l}\text { Alphitobius } \\
\text { diaperinus }\end{array}$ & A & $\begin{array}{l}0,5,20^{\circ} \mathrm{C}(24 \mathrm{~h}) ; 50{ }^{\circ} \mathrm{C}(12 \mathrm{~h}) \text { to } \\
20^{\circ} \mathrm{C}(12 \mathrm{~h}) ; 0{ }^{\circ} \mathrm{C}(20 \mathrm{~h}) \text { to } 15 \text { or } \\
20^{\circ} \mathrm{C}(4 \mathrm{~h})\end{array}$ & $\begin{array}{l}\text { Resp, Ox } \\
\text { dam: SOD, } \\
\text { GSHt, GSSG }\end{array}$ & $\begin{array}{l}\uparrow \text { SOD increased during recovery, } \\
\text { antiox sufficient to control ROS }\end{array}$ & $\begin{array}{l}\text { Lalouette } \\
\text { et al. (2011) }\end{array}$ \\
\hline & Tenebrionidae & $\begin{array}{l}\text { Alphitobius } \\
\text { diaperinus }\end{array}$ & A & $3^{\circ} \mathrm{C}(22 \mathrm{~h})$ to $20^{\circ} \mathrm{C}(2 \mathrm{~h})$ & ATP & $\begin{array}{l}\uparrow \text { survival, ATP homeostasis disrupted } \\
\text { by cold in both FTR and constant } \\
\text { temperatures }\end{array}$ & Colinet (2011) \\
\hline \multirow[t]{5}{*}{ Diptera } & Calliphoridae & $\begin{array}{l}\text { Lucilia } \\
\text { cuprinai }\end{array}$ & $\mathrm{P}$ & $10-28^{\circ} \mathrm{C}(2-3 \mathrm{~h})$ every week & $\begin{array}{l}\text { Surv, emerge, } \\
\text { resp }\left(\mathrm{O}_{2}\right)\end{array}$ & $\begin{array}{l}\uparrow \text { survival, } \downarrow \text { metabolic rate (quiescent } \\
\text { state) }\end{array}$ & $\begin{array}{l}\text { Leopold et al. } \\
\text { (1998) }\end{array}$ \\
\hline & Calliphoridae & $\begin{array}{l}\text { Lucilia } \\
\text { sericatai }\end{array}$ & $\mathrm{P}$ & $10-28^{\circ} \mathrm{C}(2-3 \mathrm{~h})$ every week & $\begin{array}{l}\text { Surv, emerge, } \\
\text { resp }\left(\mathrm{O}_{2}\right)\end{array}$ & $\begin{array}{l}\uparrow \text { survival, } \downarrow \text { metabolic rate (quiescent } \\
\text { state) }\end{array}$ & $\begin{array}{l}\text { Leopold et al. } \\
\text { (1998) }\end{array}$ \\
\hline & Drosophilidae & $\begin{array}{l}\text { Drosophila } \\
\text { melanogaster }\end{array}$ & A & $\begin{array}{l}-0.5^{\circ} \mathrm{C}(2 \mathrm{~h}) \text { with } 22{ }^{\circ} \mathrm{C}(22 \mathrm{~h}) \\
\text { daily }\end{array}$ & $\begin{array}{l}\text { Surv, fertility, } \\
\text { energy } \\
\text { reserves }\end{array}$ & $\begin{array}{l}\uparrow \text { survival, } \downarrow \text { fecundity, sex-ratio male } \\
\text { biased, } \downarrow \text { glycogen \& triglyceride }\end{array}$ & $\begin{array}{l}\text { Marshall and } \\
\text { Sinclair } \\
(2010)\end{array}$ \\
\hline & Muscidae & $\begin{array}{l}\text { Musca } \\
\text { domestica }\end{array}$ & $\mathrm{P}, \mathrm{pA}$ & $\begin{array}{l}7 \text { or } 10-28^{\circ} \mathrm{C}(2-3 \mathrm{~h}) \text { every } \\
4 \text { days }\end{array}$ & $\begin{array}{l}\text { Surv, emerge, } \\
\text { resp }\left(\mathrm{O}_{2}\right)\end{array}$ & $\begin{array}{l}\uparrow \text { survival, } \downarrow \text { metabolic rate (quiescent } \\
\text { state) }\end{array}$ & $\begin{array}{l}\text { Leopold et al. } \\
\text { (1998) }\end{array}$ \\
\hline & Sarchophagidae & $\begin{array}{l}\text { Sarcophaga } \\
\text { crassipalpis }\end{array}$ & A & $\begin{array}{l}0^{\circ} \mathrm{C} \text { (20 days) with } 15^{\circ} \mathrm{C} \text { or } \\
\left.20^{\circ} \mathrm{C} \text { pulse (day } 10\right)\end{array}$ & ATP, Surv & $\uparrow$ survival, ATP higher during pulse & $\begin{array}{l}\text { Dollo et al. } \\
(2010)\end{array}$ \\
\hline Hemiptera & Lygaeidae & $\begin{array}{l}\text { Oncopeltus } \\
\text { fasciatus }\end{array}$ & $\mathrm{E}$ & $\begin{array}{l}15^{\circ} \mathrm{C} \text { and } 25^{\circ} \mathrm{C} ; 25^{\circ} \mathrm{C}(4 \mathrm{~h}) \text { to } \\
15^{\circ} \mathrm{C}(20 \mathrm{~h}) \text { daily }\end{array}$ & Resp, BF & $\begin{array}{l}\uparrow \mathrm{O}_{2} \text { consumption at } 25^{\circ} \mathrm{C} \text { with } \\
\text { overshoot }\end{array}$ & $\begin{array}{l}\text { Richards and } \\
\text { Suanraksa } \\
(1962)\end{array}$ \\
\hline \multirow[t]{2}{*}{ Heteroptera } & Pyrrhocoridae & $\begin{array}{l}\text { Pyrrhocoris } \\
\text { aperus }\end{array}$ & A & $-5^{\circ} \mathrm{C}(22 \mathrm{~h})$ to $20^{\circ} \mathrm{C}(2 \mathrm{~h})$ & $\begin{array}{l}\text { [ions], } \\
\text { osmolality, } \\
\mathrm{H}_{2} \mathrm{O}, \mathrm{CT} \text {, Surv }\end{array}$ & $\begin{array}{l}\text { Slower chill injury, longer survival, } \\
\text { haemolymph }[\mathrm{K}+] \text { lower }\end{array}$ & $\begin{array}{l}\text { Koštál et al. } \\
\text { (2007) }\end{array}$ \\
\hline & Pyrrhocoridae & $\begin{array}{l}\text { Pyrrhocoris } \\
\text { aperus }\end{array}$ & A & $-5^{\circ} \mathrm{C}(22 \mathrm{~h})$ to $25^{\circ} \mathrm{C}(2 \mathrm{~h})$ & $\begin{array}{l}\text { Surv, Pahsp70 } \\
\text { mRNA, } \\
\text { PaHSP70 }\end{array}$ & $\begin{array}{l}\uparrow \text { survival, } \uparrow \text { Pahsp70 mRNA, no change } \\
\text { PaHSP70 }\end{array}$ & $\begin{array}{l}\text { Tollarová- } \\
\text { Borovanská } \\
\text { et al. (2009) }\end{array}$ \\
\hline \multirow[t]{3}{*}{ Hymenoptera } & Aphidiinae & $\begin{array}{l}\text { Aphidius } \\
\text { colemari }\end{array}$ & M & $4{ }^{\circ} \mathrm{C}(22 \mathrm{~h})$ with $20^{\circ} \mathrm{C}(2 \mathrm{~h})$ & $\begin{array}{l}\text { Proteins, } \\
\text { Surv }\end{array}$ & $\begin{array}{l}\uparrow \text { survival; proteins: energy } \\
\text { metabolism, protein chaperones, } \\
\text { protein degradation }\end{array}$ & $\begin{array}{l}\text { Colinet et al. } \\
\text { (2007a) }\end{array}$ \\
\hline & Aphidiinae & $\begin{array}{l}\text { Aphidius } \\
\text { colemari }\end{array}$ & M & $4^{\circ} \mathrm{C}(22 \mathrm{~h})$ with $20^{\circ} \mathrm{C}(2 \mathrm{~h})$ daily & FAA, Surv & $\uparrow$ survival, $\downarrow$ FAA pool & $\begin{array}{l}\text { Colinet et al. } \\
\text { (2007b) }\end{array}$ \\
\hline & Megachilidae & $\begin{array}{l}\text { Megachile } \\
\text { rotundata }\end{array}$ & $\mathrm{P}$ & $6-20,25$ or $15^{\circ} \mathrm{C}$ & Resp & $\begin{array}{l}\text { Cyclic pattern @ high temp, changed } \\
\text { at diff FTR }\end{array}$ & $\begin{array}{l}\text { Yocum et al. } \\
\text { (2011) }\end{array}$ \\
\hline \multirow[t]{4}{*}{ Lepidoptera } & Olethreutidae & $\begin{array}{l}\text { Epiblema } \\
\text { scudderiana }\end{array}$ & $\mathrm{L}$ & $-16^{\circ} \mathrm{C}(24 \mathrm{~h})$ to $3^{\circ} \mathrm{C}(24 \mathrm{~h})$ & Metabolites & $\begin{array}{l}\text { No diff cryop. (though fluctuate with } \\
\text { cycles) }\end{array}$ & $\begin{array}{l}\text { Churchill and } \\
\text { Storey (1989) }\end{array}$ \\
\hline & Noctuidae & $\begin{array}{l}\text { Spodoptera } \\
\text { exigua }\end{array}$ & $\mathrm{L}$ & $20: 10,20: 5,20: 0^{\circ} \mathrm{C}$ & $\begin{array}{l}\text { CT, SCP, } \\
\text { Osmolality, } \\
\text { Glycerol }\end{array}$ & $\begin{array}{l}\uparrow \mathrm{CT}(\downarrow \mathrm{SCP}, \uparrow \text { haemolymph } \\
\text { osmolalities and glycerol })\end{array}$ & $\begin{array}{l}\text { Kim and Song } \\
(2000)\end{array}$ \\
\hline & Nymphalidae & Aglais urticae & A & $-5(8 \mathrm{~h}), 10^{\circ} \mathrm{C}(16 \mathrm{~h})$ cycles & Surv, SCP & $\begin{array}{l}\downarrow \text { SCP, relative to std cold: } \uparrow \text { mass lost; } \\
\text { relative to std warm: } \uparrow \text { survival }\end{array}$ & $\begin{array}{l}\text { Pullin and } \\
\text { Bale (1989) }\end{array}$ \\
\hline & Nymphalidae & Inachis io & A & $-5(8 \mathrm{~h}), 10^{\circ} \mathrm{C}(16 \mathrm{~h})$ cycles & Surv, SCP & $\begin{array}{l}\downarrow \text { SCP, relative to std cold: } \uparrow \text { mass lost; } \\
\text { relative to std warm: } \uparrow \text { survival }\end{array}$ & $\begin{array}{l}\text { Pullin and } \\
\text { Bale (1989) }\end{array}$ \\
\hline Orthoptera & Acrididae & $\begin{array}{l}\text { Locusta } \\
\text { migratoria }\end{array}$ & $\mathrm{E}$ & Thermoperiods ( 20 to $-4^{\circ} \mathrm{C}$ ) & $\begin{array}{l}\text { Cryo, hsps, } \\
\text { SCP, Surv. }\end{array}$ & $\begin{array}{l}\uparrow \text { survival, } \uparrow \text { cryoprotectants (myo- } \\
\text { inositol, trehalose, mannitol, sorbitol), } \\
\uparrow \text { hsp } 20.5,70,90\end{array}$ & $\begin{array}{l}\text { Wang et al. } \\
\text { (2006) }\end{array}$ \\
\hline
\end{tabular}

a Lifestages: A, adult; pA, pharate adult; P, pupa; PP, prepupa; M, mummies; L, larva; E, eggs.

b Abbreviations of variables measured: [ion], ion concentration; $\mathrm{H}_{2} \mathrm{O}$, water balance; CT, cold tolerance; Surv, Survival/mortality; FAA, free fatty acids; Cryo, cryoprotectants (sugars \& polyols); Resp., Respirometry $\left(\mathrm{CO}_{2}\right.$ or $\mathrm{O}_{2}$ respirometry); Ox dam., oxidative damage; BF, body fat; hsps, heat shock proteins; $\mathrm{SCP}$, supercooling point.

exposure being lower. Indeed, the effects of dosage in temperature treatments have been identified as important for thermal experiments (see Kashmeery and Bowler, 1977; Marshall and Sinclair, 2012). However, time and temperature interactions are typically complex and difficult to predict (e.g. Nedved et al., 1998 and see discussion in Renault et al., 2004). In essence, experiments with a short recovery period at benign conditions (i.e. longer exposure to stressful conditions) may be fundamentally different to experiments with short stress exposures. Despite the fact that several studies have examined these issues (Table 1 ), the exact reasons behind this effect remains largely unresolved. The same criticisms of experimental design can be raised for FHR, specifically that doseor time-matched controls are typically not included for both constant hydration and dehydration conditions (e.g. Benoit et al., 2010). The contrasting results from FTR studies therefore highlight the need for further investigation of the effects of fluctuating stress regimes on insects. However, it is clear that an integrative approach is required to better understand the mechanisms involved in FTR and FHR. Furthermore, the integrative approach should perhaps also consider phenotypic plasticity, cellular damage and repair mechanisms (e.g. Sørensen et al., 2013), and diapause state as major influencing factors, as this may allow for more accurate 
prediction of the outcomes of repeated stress on survival and, ultimately, fitness (see discussion in e.g. Chown and Terblanche, 2007; Marshall and Sinclair, 2012).

Fluctuations in environmental conditions, such as temperature, have been well documented to affect insect stress resistance (e.g. Huey and Bennett, 1990; Terblanche et al., 2010a; Folguera et al., 2011) and insect physiology more broadly (e.g. Koštál et al., 2007). Previously it has been argued that FTR are fundamentally different from constant temperature in the calculation of insect development rates and accumulated day-degrees (see discussions in Hagstrum and Milliken, 1991; Worner, 1992). Until recently however, the physiological mechanisms underlying these differences were not well investigated (but see Richards and Suanraksa, 1962; Pullin and Bale, 1989). It is increasingly clear that insects rely on a combination of genes, proteins (e.g. heat shock proteins, enzymes, antifreeze proteins), cryoprotectants and membrane changes to survive and recover from exposure to low temperatures (reviewed in Clark and Worland, 2008; Lee, 2010; Storey and Storey 2012). At the critical thermal minimum $\left(\mathrm{CT}_{\min }\right.$; lower limit of activity), insects enter a reversible, non-lethal state of chill coma. While the onset of insect chill coma is likely determined by a combination of disruption of ion homeostasis and/or signal transmission failure (Goller and Esch, 1990; Hosler et al., 2000), and in some species, possibly also whole animal oxygen limitation (Verberk and Calosi, 2012; but see also Stevens et al., 2010), the mechanisms of recovery are typically not well understood and may not necessarily involve a reversal of the mechanisms causing induction of coma (reviewed in MacMillan and Sinclair, 2011). Therefore, the physiological mechanisms induced by FTR are likely diverse and implicate an important role for ion homeostasis, antioxidants, free fatty acids, cryoprotective sugars, proteins and energy reserves (including ATP) (an overview of mechanisms investigated to date is given in Table 1 ).

Dehydration resistance in insects is dependent on body water content, the rate of water loss, and the ability to tolerate desiccation. Common physiological mechanisms used to counteract dehydration stress include regulation of whole-animal gas exchange, ion homeostasis and osmoregulation, synthesis of proteins and cryoprotectants, and variation in cuticular hydrocarbon composition and amounts (reviewed in Hadley 1994; Benoit, 2010; Chown et al., 2011). However, physiological responses to FHR are less well studied. Two recent studies on the Antarctic midge Belgica antarctica and the mosquito Culex pipiens showed that repeated dehydration depletes energy reserves and reduces fitness (Benoit et al., 2010; Teets et al., 2012). Responses to both FTR and FHR may rely on heat shock protein 70 (HSP70) as molecular chaperones to limit the stress or repair damage to misfolded proteins, although only indirect evidence for the involvement of HSP70 has been found to date as studies investigate gene expression but not necessarily the downstream protein product (e.g. Wang et al., 2006; Teets et al., 2011; but see Tollarová-Borovanská et al., 2009). In addition, whole-animal metabolic rate may also vary in response to FTR (Leopold et al., 1998; Yocum et al., 2011; Lalouette et al., 2011). In the few studies that have investigated FTR and FHR on the same species, one potentially common response to both FTR and FHR is a depletion of energy reserves (e.g. Teets et al., 2011, 2012; Benoit et al., 2010) suggesting that whole-animal metabolic rate reductions may be a significant avenue for energy or water savings (e.g. Schimpf et al., 2009; and see discussions in Chown et al., 2011), especially given the water penalties incurred by gas exchange in terrestrial organisms (Woods and Smith 2010).

Here, using final instar larvae of the false codling moth Thaumatotibia leucotreta (Meyrick) (Lepidoptera: Tortricidae), we aimed to investigate the physiological effects of both FTR and FHR in a chillsusceptible lepidopteran. Specifically, we sought to determine whether the repeated stress has an accumulative damaging or protective effect. This species was chosen as a model organism for this study as the larvae do not have other physiological responses which may affect the outcomes of repeated stress: the larvae do not undergo diapause, have limited plasticity of supercooling point (i.e. the freezing temperature of body fluids) and low temperature mortality, and are more sensitive to the temperature of an acute exposure rather than the duration (Reed, 1974; Boardman et al., 2012; Boardman, unpublished). In the present study, we therefore measured whole-animal metabolic rate during FTR and FHR using flow-through respirometry, determined HSP70 protein levels to investigate whether it may be playing an important role in FTR or FHR, and compared whether these mechanisms may be similarly employed between FTR and FHR. We specifically chose to measure HSP70 protein as gene expression does not always reflect functional changes in proteins (see discussions in Colinet and Hoffman, 2012; Teets et al., 2013). Based on current fluctuating stress response literature (Table 1 ), we predicted that FTR would increase larval survival due to the recovery periods that allow for damage to be repaired, with little effect on body water- or lipid content (BWC and BLC respectively) or HSP70. While resting metabolic rate (RMR) during FTR would be expected to change based on temperature alone (i.e. $Q_{10}$ effects, Hochachka and Somer$o, 2002$ ) it is less clear what the net effect thereafter would be. On the one hand, FTR may result in a reduction in RMR due to the accumulation of detrimental effects of stress, or it may up-regulate RMR in order to repair damage caused during the low temperature periods (see e.g. Storey and Storey, 2004; Terblanche et al., 2010b). On the other hand, FHR could decrease larval survival given that previous work has shown FHR to decrease overall fitness, decrease BWC and BLC, and increase HSP70. FHR is further expected to decrease whole-animal metabolic rate, as this is a relatively well-documented response to dehydrating conditions (e.g. Schimpf et al., 2009; Terblanche et al., 2010b). No net change could reflect a balance between these damage accumulation and repair processes or a genuine lack of effect and may be difficult to tease apart further without detailed cellular biochemistry experimentation.

\section{Materials and methods}

\subsection{Insect rearing}

T. leucotreta larvae were obtained from XSIT, Citrusdal, maintained in an incubator (BOD-150, MRC Lab Instruments, Holon, Israel) at $25^{\circ} \mathrm{C}$ (actual mean temperature \pm SEM was $24.7 \pm 1.0^{\circ} \mathrm{C}$ ), $50 \%$ relative humidity $(\mathrm{RH}), 12: 12$, and used in FTR or FHR experiments when they reached the final instar and began to wander off the diet. During the experiments, each larva was kept individually in a $1.5 \mathrm{~mL}$ microfuge tube with air holes.

\subsection{Experimental regimes}

Larvae (total $n=832$ ) were exposed to a fluctuating thermal regime (FTR, Fig. 1A), fluctuating hydration regimes (FHR, Fig. 1B), or one of their age- or time-matched controls. At timepoints $t_{\mathrm{A}}$ to $t_{\mathrm{X}}$, sampling for different assays was done. The first timepoint $t_{\mathrm{A}}$ reflects basal physiology, prior to the onset of the experiment. The experiments all ended at $t_{\mathrm{D}}$, whereafter larvae were allowed to recover at $25{ }^{\circ} \mathrm{C}$ for $24 \mathrm{~h}$ prior to sampling at $t_{\mathrm{x}}$. During all experiments, temperatures were controlled using programmable waterbaths (CC410wl, Huber, Berching, Germany). In all cases, iButtons (DS1922L and DS1923 (accuracy $\pm 0.5^{\circ} \mathrm{C}$ and $5 \% \mathrm{RH}$ ), Dallas Semiconductors, Dallas, Texas, USA) were used in combination with glass thermometers and an infrared thermometer (accuracy $\pm 2{ }^{\circ} \mathrm{C}$, Fluke 63 IR Thermometer, Fluke UK Ltd., Norwich, UK) to 

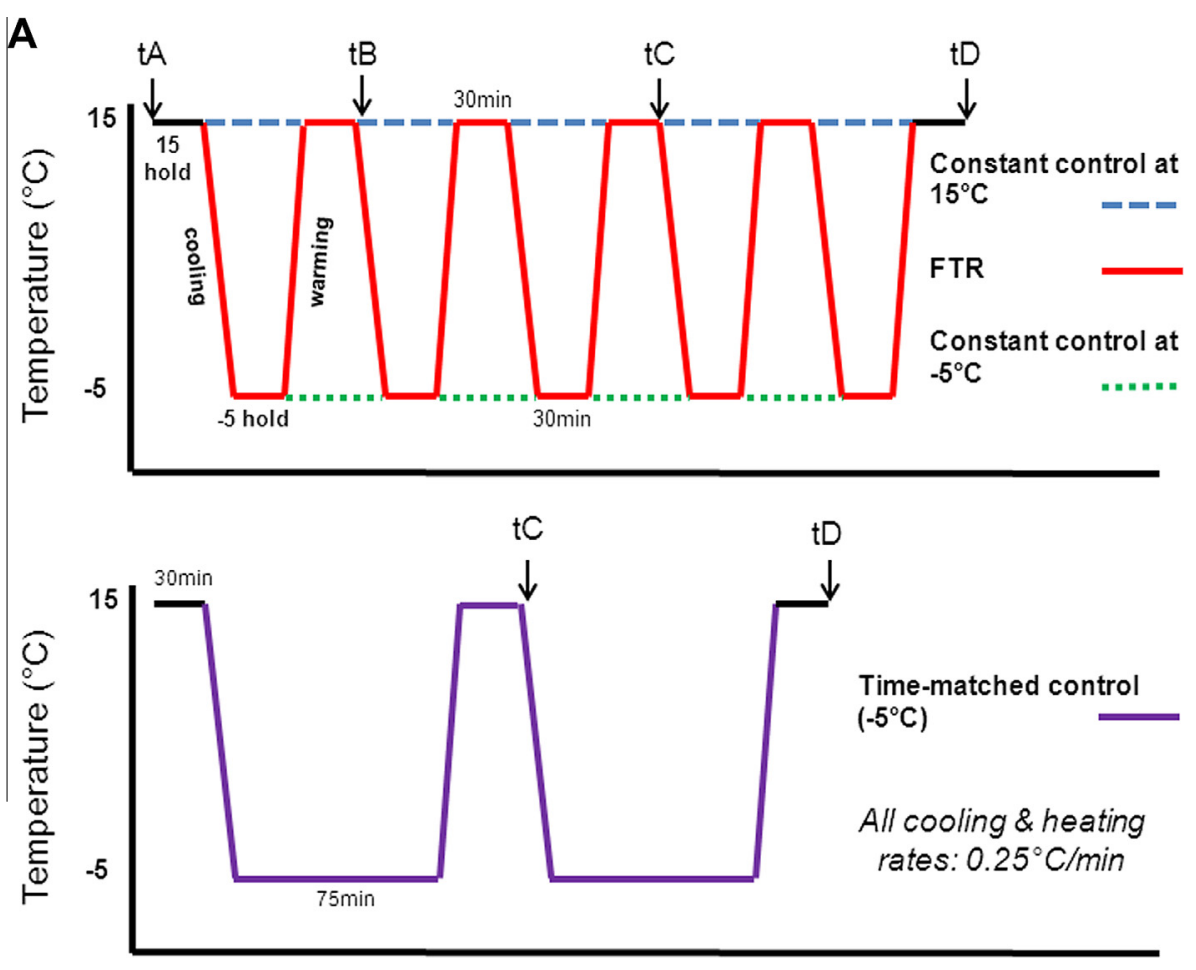

Time

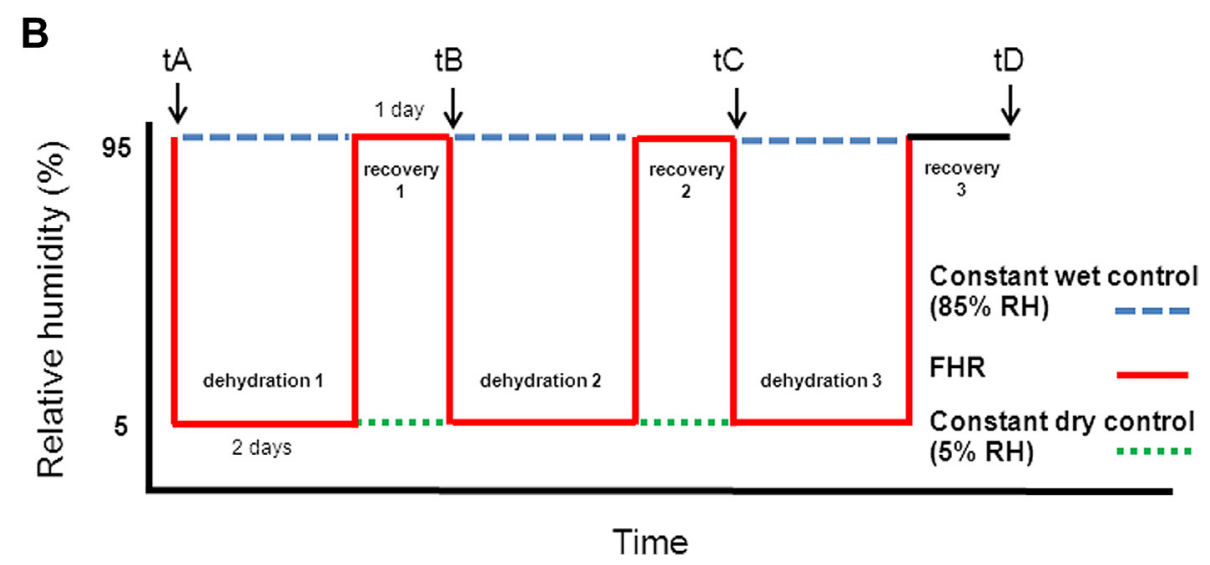

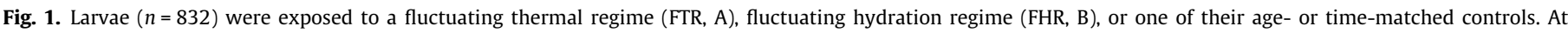

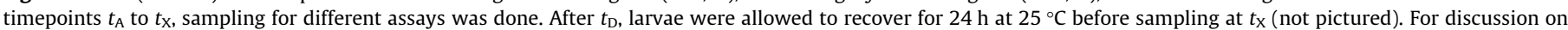

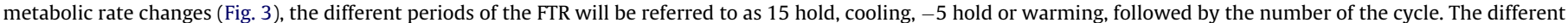

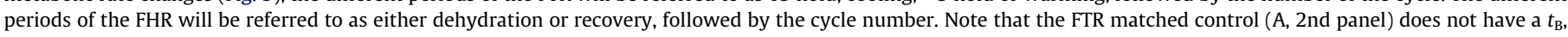
and that $t_{\mathrm{C}}$ for this experiment is not exactly the same time exposure as $t_{\mathrm{C}}$ for the other FTR experiments, but will be referred to as such to facilitate comparison.

monitor and record temperature. All temperatures are given as mean $( \pm$ SEM).

\subsubsection{Fluctuating thermal regimes (FTR)}

To investigate the effects of FTR, larvae were held at $15^{\circ} \mathrm{C}$ for $30 \mathrm{~min}$ (" 15 hold" period), before being cooled from $15^{\circ} \mathrm{C}$ to $-5{ }^{\circ} \mathrm{C}$ at $0.25^{\circ} \mathrm{C} / \mathrm{min}$ ("cooling" period). After $30 \mathrm{~min}$ at $-5^{\circ} \mathrm{C}$ (" -5 hold" period), the larvae were rewarmed to $15^{\circ} \mathrm{C}$ at $0.25^{\circ} \mathrm{C} / \mathrm{min}$ ("warming" period) and held at $15^{\circ} \mathrm{C}$ for $30 \mathrm{~min}$. This cycling was repeated five times (Fig. 1A). After the final $15^{\circ} \mathrm{C}$ for 30 min at timepoint $\mathrm{D}\left(t_{\mathrm{D}}\right)$, larvae were removed from waterbath and placed in an incubator set at $25{ }^{\circ} \mathrm{C}$ to monitor larval survival and further development. Larvae were removed from the FTR at each timepoint $\left(t_{\mathrm{A}}\right.$ to $t_{\mathrm{X}}$, Fig. 1A) for immediate BWC and BLC assays, or frozen at $-80^{\circ} \mathrm{C}$ for HSP70 assay. Fifth instar T. leucotreta larvae enter chill coma $\left(\mathrm{CT}_{\text {min }}\right)$ at $6.7 \pm 0.1{ }^{\circ} \mathrm{C}$ using this same starting temperature and cooling rate (Boardman et al., 2012), and all larvae are able to resume full activity (i.e. walking) within ten minutes of removal from exposure to $-1^{\circ} \mathrm{C}$ for $2 \mathrm{~h}$ (Boardman, unpublished). Therefore, the FTR was chosen to fluctuate around a value close to the $\mathrm{CT}_{\min }$, with a mean FTR temperature during the fluctuations (i.e. without the $24 \mathrm{~h}$ recovery) of $5.5 \pm 0.5^{\circ} \mathrm{C}$. In addition, $-5^{\circ} \mathrm{C}$ was chosen as a non-lethal low temperature to ensure that all larvae were in a complete state of chill coma (lethal temperature for $50 \%$ of the population is $-11.5 \pm 0.3{ }^{\circ} \mathrm{C}$ after $2 \mathrm{~h}$, and the mean freezing point is $-15.6 \pm 0.6^{\circ} \mathrm{C}$ ), and ramping rates were the same as previous studies (see Boardman et al., 2012).

Age controls for the FTR consisted of two constant temperature experiments held at either $15^{\circ} \mathrm{C}$ or $-5^{\circ} \mathrm{C}$ for the same duration as the FTR experiment (referred to as constant control $15^{\circ} \mathrm{C}$ and constant control $-5^{\circ} \mathrm{C}$ ). An additional time-matched control consisting of two cycles of being cooled from $15^{\circ} \mathrm{C}$ to $-5^{\circ} \mathrm{C}$ at $0.25^{\circ} \mathrm{C}$ / 
min, 75 min at $-5^{\circ} \mathrm{C}$, rewarmed to $15^{\circ} \mathrm{C}$ at $0.25^{\circ} \mathrm{C} / \mathrm{min}$, and held at $15^{\circ} \mathrm{C}$ for $30 \mathrm{~min}$, was also used (see Kashmeery and Bowler, 1977; Marshall and Sinclair, 2012). The mean temperature during the time-matched control was $4.9 \pm 0.5^{\circ} \mathrm{C}$. Note that the FTR time-matched control does not have a $t_{\mathrm{B}}$, and that $t_{\mathrm{C}}$ for this experiment is not exactly the same time exposure as $t_{\mathrm{C}}$ for the other FTR experiments, but will be referred to as such to facilitate comparison (Fig. 1). The mean temperatures experienced in the waterbath for $-5^{\circ} \mathrm{C}$ periods were $-3.43 \pm 0.5^{\circ} \mathrm{C}$, while $15^{\circ} \mathrm{C}$ was more easily obtained $\left(15.50 \pm 0.5^{\circ} \mathrm{C}\right)$.

\subsubsection{Fluctuating hydration regimes (FHR)}

To investigate the effects of FHR, larvae were kept at $25^{\circ} \mathrm{C}$ and cycled between high and low RH (means were $85.2 \pm 10 \%$ and $9.4 \pm 5 \%$, respectively) every 3 days (i.e. 2 days dehydrated, 1 day recovery) and cycling between low and high $\mathrm{RH}$ was repeated three times (Fig. 1B). To determine time-to-death from either dehydration or starvation, larvae were kept under either starvation $(>90 \% \mathrm{RH})$ or starvation with dehydration $(\sim 10 \% \mathrm{RH})$ conditions. These results showed that larvae survive at least 10 days without access to food, and at death, have lost approximately $50 \%$ of their initial body mass and approximately $65-80 \%$ of their initial BWC (Fig. S1). Therefore, the experimental duration was chosen to maximise the stress duration, while minimizing starvation-related mortality. In order to assess daily body mass changes over the 10 day FHR duration, a separate 20 individuals were weighed daily, and larval survival, pupation- and emergence were monitored.

Larvae exposed to FHR were kept individually in microfuge tubes with air holes placed inside $5.5 \mathrm{~L}$ plastic containers plumbed to allow airflow. Air from an aquarium pump was manually switched between dry air from scrubber columns containing 50:50 silica gel:Drierite (WA Hammond Drierite Company Ltd., Ohio, USA) and moist air at $>90 \% \mathrm{RH}$, humidified using a custom made air bubbler kept at room temperature $\sim 25^{\circ} \mathrm{C}$ (see Stevens et al., 2010). After the experiment, larvae were kept in an incubator set at $25^{\circ} \mathrm{C}$ to monitor larval survival and further development. Age controls in FHR consisted of two experiments that were held at constant $\mathrm{RH}$, either $85 \% \mathrm{RH}$ (constant wet control) or $10 \% \mathrm{RH}$ (constant dry control), for 8 days at $25^{\circ} \mathrm{C}$.

\subsection{Assays}

\subsubsection{Flow-through respirometry}

To determine whether whole-animal metabolic rate changes were occurring during the FTR or FHR experiments, we used flow-through respirometry to simultaneously measure gas exchange as carbon dioxide and water output with a Li-7000 infrared $\mathrm{CO}_{2} / \mathrm{H}_{2} \mathrm{O}$ analyser (IRGA, LiCor, Lincoln, Nebraska, USA), in conjunction with electronically-recorded activity (Fig. 2). All individuals' masses were recorded before and after each respirometry run (accuracy $\pm 0.0001 \mathrm{~g} ;$ AB104-S/Fact, Mettler Toledo International, Inc.) and inserted into custom-built $3 \mathrm{~mL}$ plastic respirometry cuvettes. Baseline recordings of the calibrated IRGA were taken before and after experiments and analyser drift was corrected prior to data extraction and analyses. For both FTR and FHR, temperature was controlled using a programmable waterbath set to follow the FTR or FHR protocol (Fig. 1).

Gas exchange during FTR was measured in individual larvae ( $n=11$ ) using a standard push mode respirometry setup (see Lighton, 2008). Air from an aquarium pump was scrubbed of $\mathrm{CO}_{2}$ and $\mathrm{H}_{2} \mathrm{O}$ by two columns containing soda lime, and 50:50 silica gel:Drierite (WA Hammond Drierite Company Ltd., Ohio, USA) respectively. Airflow was regulated at $200 \mathrm{~mL} \mathrm{~min}^{-1}$ using a mass flow control valve (Sidetrak, Sierra International, USA) connected to a mass flow control box (Sable Systems, Las Vegas, Nevada, USA) and fed through the cuvette to a calibrated IRGA plumbed
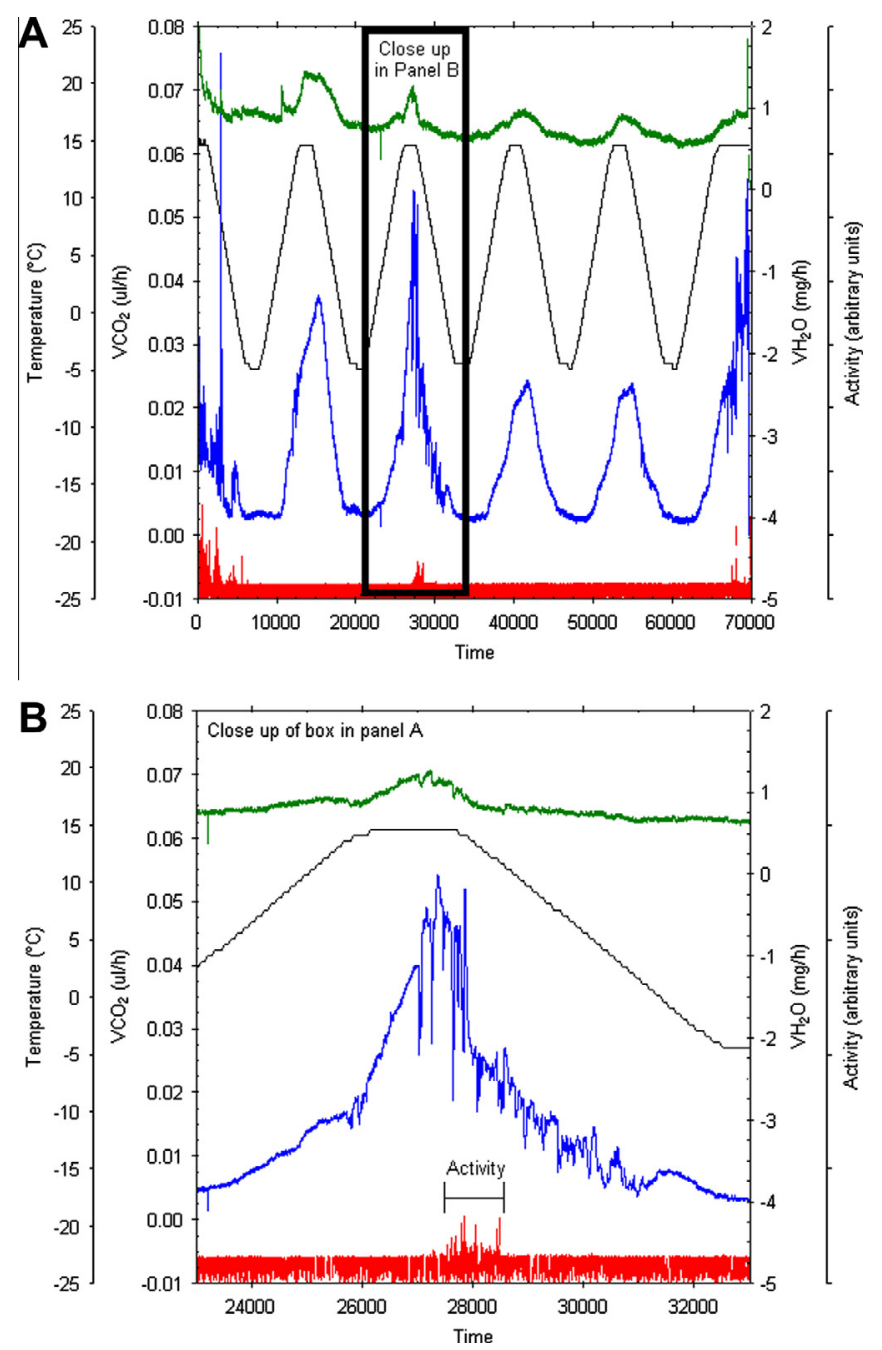

Fig. 2. An example of a fluctuating thermal regime (FTR) experiment showing simultaneous $\mathrm{CO}_{2}$ output (middle/blue line, left axis), $\mathrm{H}_{2} \mathrm{O}$ output (top/green line, right axis), activity (bottom/red line) and temperature (ibutton, middle/black line, left secondary axis). $\dot{V} \mathrm{CO}_{2}$ fluctuates with temperature and $\dot{V} \mathrm{H}_{2} \mathrm{O}$ increases when $\dot{V} \mathrm{CO}_{2}$ increases. The black box indicated in panel $\mathrm{A}$, is shown in panel $\mathrm{B}$ at a finer scale to illustrate a period of activity. Active gas exchange, indicated by spikes in the activity trace, is visible during the first $30 \mathrm{~min}$ hold at $15^{\circ} \mathrm{C}$, recovery at $15^{\circ} \mathrm{C}$ after two cycles (approx. 28,000 s) and at the end of the cycling. (For interpretation of the references to color in this figure legend, the reader is referred to the web version of this article.)

in differential mode (see Lighton, 2008). The analyser was connected to a desktop PC via RS-232 connection to record $\mathrm{CO}_{2}$ production (in parts per million) and $\mathrm{H}_{2} \mathrm{O}$ loss (in parts per thousand) using LiCor software. The cuvette was placed inside several plastic bags before being submerged in a programmable waterbath set to follow the FTR protocol (Fig. 1A).

For the FHR, multiplexed respirometry was used (following Basson and Terblanche, 2011) to record $\mathrm{CO}_{2}$ and $\mathrm{H}_{2} \mathrm{O}$ output in seven individuals. Seven $3 \mathrm{~mL}$ custom-built respirometry cuvettes were used, with one of them recording activity (as per FTR respirometry). Cuvettes were maintained at $25^{\circ} \mathrm{C}$ and each respirometry cuvette was recorded for $30 \mathrm{~min}$ with a baseline of $30 \mathrm{~min}$ before each set of recordings (i.e. each individual was sampled once every $4 \mathrm{~h}$ cycle). Air was manually switched between dry air (directly from scrubber columns) and moist air as per FHR description above (Section 2.2.2). Before the moist air reached the gas analyser cell , it was passed through a small custom made scrubber column containing reactivated Drierite to remove the water vapour (see White 
et al., 2006). Therefore, FHR data from the water channel could only be used during the dehydration period owing to high background noise and limitations of IRGA accuracy.

\subsubsection{Measurement of body water- and lipid content (BWC and BLC)}

To determine the effects of FTR and FHR on BWC and BLC, 20 larvae from each timepoint ( $t_{\mathrm{A}}$ to $t_{\mathrm{X}}$; Fig. 1) of each experiment plus each of their controls were assayed using gravimetric methods. Larvae were weighed on an electronic microbalance to determine the fresh mass. The larvae were then placed in an oven (IncoTherm $\mathrm{S}$, Labotec, South Africa) at $45{ }^{\circ} \mathrm{C}$ for 3 days until a stable, dry body mass was reached which was then recorded. Thereafter, larvae were soaked in a 1:1 chloroform: methanol solution (which was changed daily) for 3 days. After the final solution was removed, larvae were air-dried in a fume hood until all the solution had evaporated, and re-weighed to determine the residual, fat-free body mass. The difference between dry mass and fresh mass was considered to be body water content, and body lipid content was calculated as the difference between fat-free mass and dry mass.

\subsubsection{Total protein concentration}

In order to assess changes in total protein concentration, three to six individuals were removed from each experiment and their respective controls at each timepoint $\left(t_{\mathrm{A}}\right.$ to $\left.t_{\mathrm{X}}\right)$ and immediately frozen at $-80^{\circ} \mathrm{C}$ until analysis. Prior to protein extraction, individuals were thawed from $-80^{\circ} \mathrm{C}$ and masses were recorded using a microbalance. Protein samples were obtained by homogenising whole individual larvae in $400 \mu \mathrm{L}$ cold phosphate buffered saline (PBS) containing $2 \mathrm{mM}$ PEFAbloc and a 1\% volume antiprotease cocktail $(100 \mu \mathrm{L} / \mathrm{mL}$ pepstatin $\mathrm{A}, 50 \mu \mathrm{L} / \mathrm{mL}$ leupeptin, $10 \mathrm{mM}$ benzamidine, $10 \mathrm{mM}$ sodium metabisulfite) (Karl et al., 2009). The homogenate was centrifuged at $4{ }^{\circ} \mathrm{C}, 11,000 \mathrm{~g}(13,000 \mathrm{rpm})$ for $30 \mathrm{~min}$ and the supernatant was transferred to a new microfuge tube. The protein concentration of the supernatant was quantified using a BCA assay kit (Pierce, Thermo Fischer Scientific Inc., USA) and samples were stored at $-80^{\circ} \mathrm{C}$ until HSP70 measurement.

\subsubsection{Heat shock protein 70 (HSP70) measurement}

In order to determine whether heat shock protein 70 was involved in FTR or FHR, HSP70 was measured in three to six individuals from each timepoint ( $t_{\mathrm{A}}$ to $t_{\mathrm{X}}$; Fig. 1 ) of each experimental and control group using a standard enzyme linked immunosorbent assay (ELISA) procedure. Western blotting was performed following Clusella-Trullas et al. (in press) to confirm that the selected antibodies bound specifically to a $70 \mathrm{kDa}$ protein in $T$. leucotreta as well as an HSP70 positive control (HeLa cytoplasmic lysate, Abcam, Cambridge, UK) and that non-specific binding did not occur (Fig. S2). An HSP70 standard was made by combining $50 \mu \mathrm{L}$ total proteins from each of six samples of $T$. leucotreta that showed positive HSP70 response using Western blotting.

Each $T$. leucotreta total protein sample was thawed from $-80^{\circ} \mathrm{C}$ and diluted in carbonate-bicarbonate buffer ( $\mathrm{pH}$ 9.6; Sigma C3041) to $30 \mu \mathrm{g} / \mathrm{mL}$ and $0.2 \mathrm{~mL}$ of this antigen coating solution was loaded into each well of a clear microtiter plate (Maxisorp, Nunc Immuno $^{\mathrm{TM}}$ plates, Sigma M9410-1CS) and incubated (covered) overnight at $4{ }^{\circ} \mathrm{C}$. The outside wells of each plate were left blank to avoid potential edge effects. Each sample was run in duplicate on each plate, and plates were replicated twice. Each plate included duplicates of the T. leucotreta HSP70 standard sample, as well as blanks to allow for correction for interplate variation, as well as background effects. The plates were washed three times in washing buffer (PBS-T: $10 \mathrm{mM}$ phosphate buffer $\mathrm{pH} 7.4,150 \mathrm{mM} \mathrm{NaCl}$, 0.05\% Tween 20-Sigma P3563) to remove the coating buffer. The wells were blocked by adding $0.2 \mathrm{~mL}$ of $5 \%$ BSA-PBS solution (Sigma A2153; $10 \mathrm{mM}$ phosphate buffer, $\mathrm{pH} 7.4,150 \mathrm{mM} \mathrm{NaCl}$ (Sigma P4417), 0.1\% sodium azide (Sigma S2002)) to each well and incubating the plate at room temperature for $1 \mathrm{~h}$. The plate was once again washed three times before adding $0.2 \mathrm{~mL}$ of diluted monoclonal anti-heat shock protein 70 antibody produced in mouse, clone BRM-22 (1:5000; Sigma H5147). The primary antibody detects both the constitutive (HSP73) and inducible (HSP72) forms of HSP70 (hereafter referred to as HSP70). Each plate was incubated at room temperature for $2 \mathrm{~h}$, and then washed

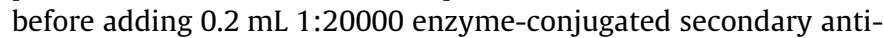
body (HRP-conjugated rabbit anti-mouse IgG, Abcam \#6728) in PBS-T and incubating at room temperature for $2 \mathrm{~h}$. The plate was washed before detection using SIGMAFAST ${ }^{\mathrm{TM}}$ OPD tablets (Sigma P9187). After $30 \mathrm{~min}$ at room temperature, the reaction was stopped using $50 \mu \mathrm{L} 3 \mathrm{M} \mathrm{HCl}$. The plates were covered with foil and stored overnight at $4{ }^{\circ} \mathrm{C}$ before reading absorbance at $490 \mathrm{~nm}$ (EL800UV Universal microplate reader, Biotek Instruments Inc. - software: KC Junior v 1.41.3, Biotek Instruments Inc.).

The absorbance value of the blank for each plate was subtracted from each samples' absorbance to account for background. Duplicated sample absorbance on each plate was averaged and then scaled relative to the plate standard (i.e. standard $=1$ ). The sample amount $(\mu \mathrm{g} / \mathrm{mL})$ and optimal antibody concentrations were determined using titration assays. The linearity of the ELISA reaction was confirmed using a dilution series of sample containing HSP70. The total protein concentration of all samples in the series was made up to $30 \mu \mathrm{g} / \mathrm{mL}$ using $1 \mathrm{mg} / \mathrm{mL}$ BSA standard. The relative absorbance of these samples verified a linear signal with increasing amounts of HSP70 at $30 \mu \mathrm{g} / \mathrm{mL}$ protein concentrations $(r>0.99)$.

\subsubsection{Fitness estimates: larval survival, pupation and emergence}

Larvae were exposed to FTR, FHR or one of the respective control experiments in order to assess fitness (measured as larval survival, pupation and emergence at $t_{\mathrm{X}}$ ). Sample sizes varied between nine and 53 due to larval availability. The 20 individuals that were weighed daily for FHR mass changes, together with those used during FTR and FHR respirometry runs, were also scored for larval survival. At $t_{\mathrm{X}}$, individuals were randomly selected for assays, and the remaining larvae were kept at $25^{\circ} \mathrm{C}$ and allowed to pupate and emerge. Pupation and emergence were calculated as a percentage of the number of remaining larvae that were monitored for pupation. Larval mortality was scored as failure to respond to stimulation with soft forceps, and pupa were scored as dead when they were unable to wriggle their abdomen in response to touch and had not emerged within 4 months.

\subsection{Statistical analyses}

Respirometry data were extracted in Expedata v. 1.1.25 (Sable Systems, Las Vegas, Nevada, USA) using custom written macros. Data were corrected for baseline drift and converted to $\mu \mathrm{L} / \mathrm{h}$ for $\dot{V} \mathrm{CO}_{2}$ and $\mathrm{mg} / \mathrm{h}$ for $\dot{V} \mathrm{H}_{2} \mathrm{O}$ using standard conversions. Data for FTR and FHR was extracted for each period (Fig. 1). For FTR, mean $\dot{V} \mathrm{CO}_{2}$ and $\dot{V} \mathrm{H}_{2} \mathrm{O}$ were extracted, and excretion events and activity during periods of recovery were counted. For FHR multiplexed data, mean $\dot{V} \mathrm{CO}_{2}$ and $\dot{V} \mathrm{H}_{2} \mathrm{O}$ for each of the central $25 \mathrm{~min}$ of each sampling period were averaged for each individual. $\dot{V} \mathrm{CO}_{2}$ includes periods of activity, as resting metabolic rate was not obtainable for all time periods (e.g. active $\dot{V} \mathrm{CO}_{2}$ during $15^{\circ} \mathrm{C}$ in FTR for the entire $30 \mathrm{~min}$ of sampling). Differences in respirometry means during different periods were compared using a generalized linear model (GLZ, normal distribution, identity link function), with start mass included as an independent variable.

Given the high correlation between replicate ELISA plates $(r=0.81, P<0.001)$ average absorbance for each sample was used in all analyses. Thawed mass was significantly correlated with total protein concentration $(r=0.65, P<0.0001)$ and HSP70 $(r=0.68$, 
$P<0.0001$ ), therefore data were divided by the individuals' thawed mass to account for mass-effects between experimental groups and trials. Data outliers that were 1.5 times larger than the group mean were deleted before HSP70 analysis leaving $n=2-6$ per HSP70 sampling point. A GLZ (using a normal distribution and identity link function) was used to assess the effects of experiment and timepoint on the larval BWC, BLC and HSP70. Larvae that died during the course of the FHR experiments were excluded from BWC and BLC analysis. To examine the effects of the different FTR and FHR experimental regimes on larval survival, pupation and emergence, experiments were compared using a generalized linear model (GLZ) with a binomial distribution, logit link function and correction for over-dispersion.

FTR and FHR data were analysed separately except for larval survival data. Differences in least squares means were used to determine which groups were significantly different. All GLZ analyses were performed in SAS 9.1 (SAS Institute, Cary, NC, USA). Significance level was $P<0.05$ for all analyses and all values presented are mean \pm SEM unless otherwise stated.

\section{Results}

\subsection{Effects of FTR and FHR on $\dot{V} \mathrm{CO}_{2}$ and $\dot{V} \mathrm{H}_{2} \mathrm{O}$}

The metabolic rate of larvae exposed to FTR closely follows the temperature regime, decreasing as the temperature decreases and increasing during recovery periods at higher benign temperatures (Fig. 2). Both $\dot{V} \mathrm{CO}_{2}$ and $\dot{V} \mathrm{H}_{2} \mathrm{O}$ were significantly affected by period $\left(\chi^{2}=274.8, \mathrm{DF}=20, P<0.0001 ; \chi^{2}=122.6, \mathrm{DF}=20, P<0.0001\right.$; Table S1). While differences between $\dot{V} \mathrm{CO}_{2}$ periods were detected (Fig. $3 \mathrm{~A}$ ), the $\dot{V} \mathrm{CO}_{2}$ was comparable within the same type of period for all periods except "15 hold 1" which was significantly higher than the subsequent holds at $15^{\circ} \mathrm{C}$. Prior to the start of the $1 \mathrm{st}$ cooling period of FTR, all 11 individuals showed active gas exchange, identified using recordings of the electronic activity detector and $\dot{V} \mathrm{CO}_{2}$ simultaneously. As the FTR progressed, the number of individuals showing active gas exchange decreased. $\dot{V} \mathrm{H}_{2} \mathrm{O}$ was significantly higher during the first fluctuating cycle than later in the experiment and remained stable after the initial decrease (Fig. 3B).

The $\dot{V} \mathrm{CO}_{2}$ of larvae exposed to FHR showed that $\dot{V} \mathrm{CO}_{2}$ was significantly affected by period $\left(\chi^{2}=30.7, \quad \mathrm{DF}=6, \quad P<0.0001\right.$, Table S1). Larval $\dot{V} \mathrm{CO}_{2}$ was up-regulated during the first dehydration period, while for the rest of the FHR, larval $\dot{V} \mathrm{CO}_{2}$ was comparable to metabolic rate recorded in larvae at $25^{\circ} \mathrm{C}\left(25^{\circ} \mathrm{C}\right.$ data from Boardman, unpublished; Fig. 3C). However, larval $\dot{V} \mathrm{H}_{2} \mathrm{O}$ was not significantly different between periods $\left(\chi^{2}=4.3, \mathrm{DF}=3, P=0.23\right.$; Fig. 3C). Larval mass was significantly affected $\dot{V} \mathrm{H}_{2} \mathrm{O}$ in FTR $\left(\chi^{2}=14.6, \mathrm{DF}=1, P=0.0001\right)$, and $\dot{V} \mathrm{CO}_{2}$ in $\mathrm{FHR}\left(\chi^{2}=6.8, \mathrm{DF}=1\right.$, $P=0.0093)$, but not $\dot{V} \mathrm{CO}_{2}$ in FTR, nor $\dot{V} \mathrm{H}_{2} \mathrm{O}$ in FHR.

\subsection{Effects of FTR and FHR on body mass, water- and lipid content}

The mean masses of larvae at the start of FTR and FHR $\left(t_{\mathrm{A}}\right)$ were not significantly different $(39.5 \pm 1.9 \mathrm{mg}$ and $44.8 \pm 2.2 \mathrm{mg}$, respectively; $\left.t_{48}=-1.8, P=0.08\right)$. However, larval BWC and BLC were significantly different between FTR and FHR at $t_{\mathrm{A}}\left(t_{48}=-3.5, P<0.01\right.$; $t_{48}=-2.0, P<0.05$; Fig. 4). Larvae exposed to FHR lost a significant amount of water over the course of the experiment $\left(F_{7,146}=14.1\right.$, $P<0.0001)$. On average, each larva lost $17.5 \mathrm{mg}$ after 10 days, with the most mass lost during the first 3 days $(10 \mathrm{mg})$, followed by $5 \mathrm{mg}$ over the next 3 days (Fig. S3). No increase in body mass occurred during recovery days, indicating that absorption of atmospheric moisture (i.e. rehydration) did not occur during recovery periods. The body mass of larvae exposed to FHR and both of the constant RH controls decreased significantly during the first 3 days (by $t_{\mathrm{B}}$ ). Mass lost during FHR (as a \% of start mass) was comparable to mass lost during constant dry control, but was significantly different to the constant wet control at $t_{\mathrm{D}}$. At $t_{\mathrm{D}}$, larvae exposed to FHR had lost $43.9 \%$ of their original start mass, while the constant wet control had only lost 29.7\% $\left(t_{25}=3.3, P<0.003\right.$; data not shown). The differences in mass between FHR and the age controls were not significant at $t_{\mathrm{X}}$ (mass lost in $\mathrm{FHR}=40.0 \%$, constant wet control $=36.8 \%$, constant dry control $=38.0 \%$ ).

The BWC of larvae during both FTR and FHR was affected by experiment and timepoint (FTR: $\chi^{2}=42.7, \mathrm{DF}=3, P<0.0001$ and $\chi^{2}=123.4, \mathrm{DF}=3, P<0.0001$ respectively; FHR: $\chi^{2}=33.2, \mathrm{DF}=2$, $P<0.0001$ and $\chi^{2}=339.6, \quad \mathrm{DF}=4, \quad P<0.0001$ respectively; Table S1, Fig. 4). Larval BWC during FTR was significantly lower than BWC at $t_{\mathrm{A}}$, and was significantly lower than the BWC of all three of the age- and time-matched controls at $t_{\mathrm{C}}$ and $t_{\mathrm{D}}$. By $t_{\mathrm{X}}$, there was no significant difference in larval BWC between the FTR and any of the FTR controls (Fig. 4A). Larval BWC during FHR and FHR controls were significantly lower than $t_{\mathrm{A}}$ (Fig. 4B). The BWC of larvae exposed to constant wet control was significantly higher than in larvae exposed to FHR at both $t_{\mathrm{B}}$ and $t_{\mathrm{D}}$ (Fig. $4 \mathrm{~B}$ ). The BLC of larvae exposed to FTR was affected by both experiment and timepoint $\left(\chi^{2}>8.19, \mathrm{DF}=3, P=0.04\right.$; Table S1). Larval BLC during FTR were all comparable to $t_{\mathrm{A}}$, except at $t_{\mathrm{B}}$ where the constant control $-5{ }^{\circ} \mathrm{C}$ was significantly lower (Fig. 4C). Larvae exposed to FHR and both the constant $\mathrm{RH}$ controls showed a decrease in BWC and BLC relative to $t_{\mathrm{A}}$ (Fig. $4 \mathrm{~B}$ and D). Only timepoint, but not experiment, had a significant effect on the BLC of larvae exposed to FHR $\left(\chi^{2}=49.68, \mathrm{DF}=4, P<0.0001\right.$; Table S1). At all the timepoints measured, with the exception of the constant wet control at $t_{\mathrm{B}}$, larval BLC was significantly lower than at $t_{\mathrm{A}}$ (Fig. 4D). At $t_{\mathrm{D}}$, the BLC of larvae in the constant wet control experiment was significantly lower than in FHR.

\subsection{Effects of FTR and FHR on total protein concentration and heat shock protein 70}

Both total protein concentration and HSP70 in larvae exposed to the FTR or constant controls were significantly influenced by experiment $\left(\chi^{2}=95.6, \mathrm{DF}=3, P<0.0001\right.$ and $\chi^{2}=41.9, \mathrm{DF}=3$, $P<0.0001)$, but not timepoint $\left(\chi^{2}=7.8, \mathrm{DF}=4, P=0.10\right.$ and $\left.\chi^{2}=3.0, \mathrm{DF}=4, P=0.56\right)$, and there was a significant interaction effect between these $\left(\chi^{2}=48.2, \mathrm{DF}=8, P<0.0001\right.$ and $\chi^{2}=16.1$, $\mathrm{DF}=8, P=0.04$; Table S1, Fig. $5 \mathrm{~A}$ and $\mathrm{C}$ ). Total protein concentration remained unchanged over the course of the FTR experiment. A significant reduction in total protein concentration occurred during the constant control at $15{ }^{\circ} \mathrm{C}$ at $t_{\mathrm{B}}, t_{\mathrm{C}}$ and $t_{\mathrm{D}}$. Larval HSP70 during $t_{\mathrm{B}}$ to $t_{\mathrm{D}}$ of the FTR remained comparable to $t_{\mathrm{A}}$ (basal) levels. However, HSP70 at $t_{\mathrm{X}}$ was significantly higher than HSP70 at both $t_{\mathrm{A}}$ and $t_{\mathrm{B}}$. No associated increase in total protein concentration was detected (Fig. 5A). Larval HSP70 in some of the age- and timematched controls was significantly lower than HSP70 at $t_{\mathrm{C}}$ and $t_{\mathrm{D}}$ in the FTR (Fig. 5C ). At $t_{\mathrm{X}}$, HSP70 in all the controls was significantly lower than in larvae exposed to the FTR.

The total protein concentration and HSP70 in larvae subjected to FHR or constant controls were not affected by experiment $\left(\chi^{2}=1.9, \mathrm{DF}=2, P=0.38\right.$ and $\left.\chi^{2}=0.1, \mathrm{DF}=2, P=0.95\right)$ or timepoint $\left(\chi^{2}=3.7, \mathrm{DF}=4, P=0.44\right.$ and $\left.\chi^{2}=1.39, \mathrm{DF}=4, P=0.85\right)$. There was an interaction effect between these two $\left(\chi^{2}=16.0, \mathrm{DF}=6, P=0.01\right)$ for HSP70, but not for total protein concentration $\left(\chi^{2}=0.9, \mathrm{DF}=6\right.$, $P=0.99$; Table S1, Fig. 5B and D). No significant differences in total protein concentration occurred during the different timepoints of the FHR or its controls. Likewise, the controls did not differ from the FHR at any of the timepoints (Fig. 5B). The HSP70 in larvae subjected to FHR was equivalent to basal $\left(t_{\mathrm{A}}\right)$ levels throughout the experiment (Fig. 5D). HSP70 decreased significantly between $t_{\mathrm{C}}$ and $t_{\mathrm{D}}$ of the FHR. During the recovery period $\left(t_{\mathrm{X}}\right)$, HSP70 increased 


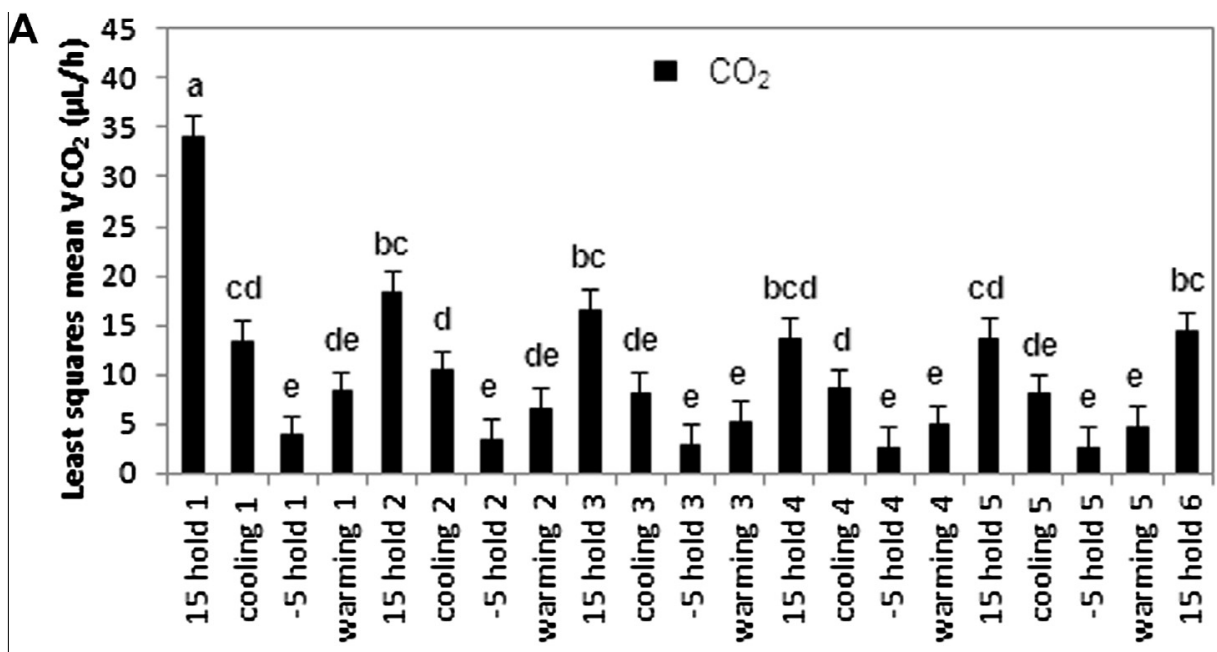

Period

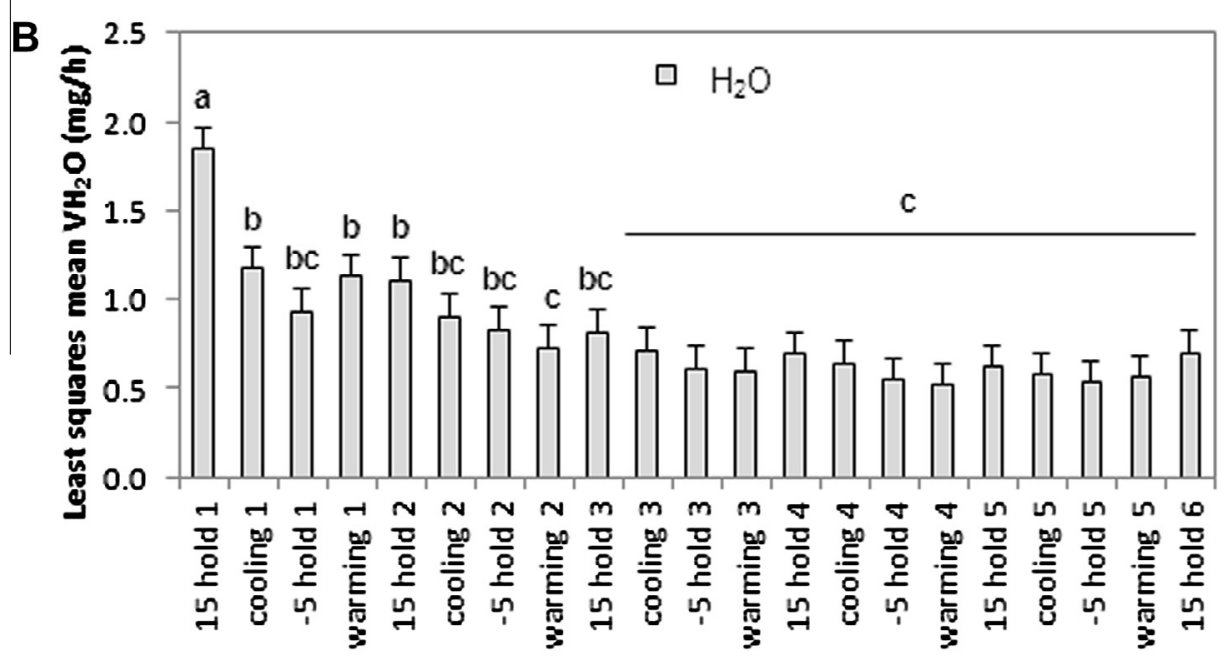

Period

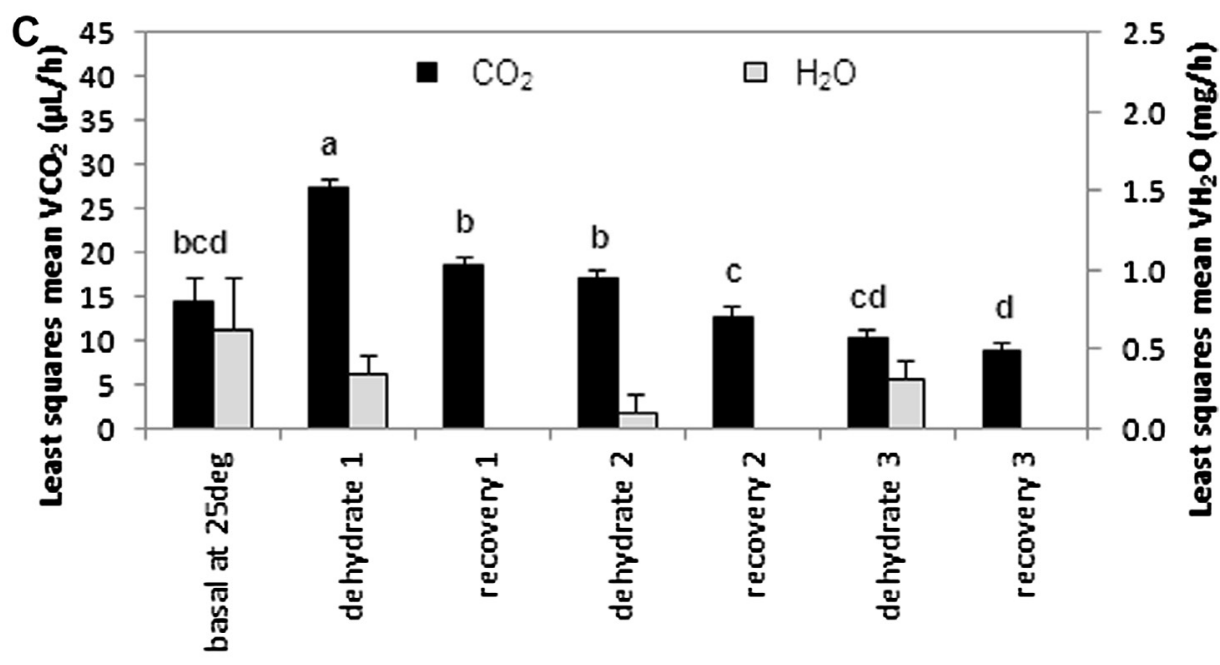

Period

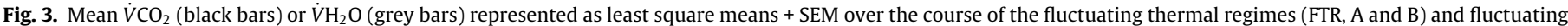

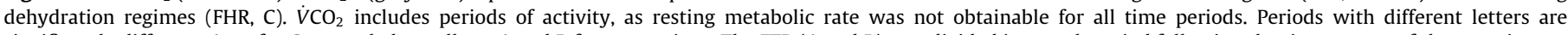

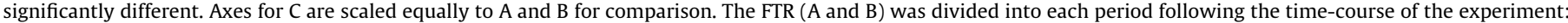

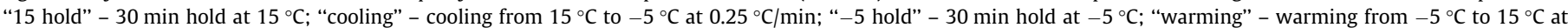

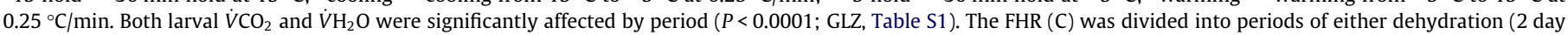

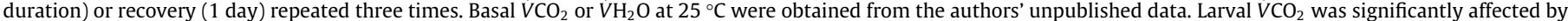
period $\left(P<0.0001\right.$; GLZ, Table S1), while larval $\dot{V} \mathrm{H}_{2} \mathrm{O}$ was not significantly different between periods $(P=0.23$; GLZ, Table S1). 

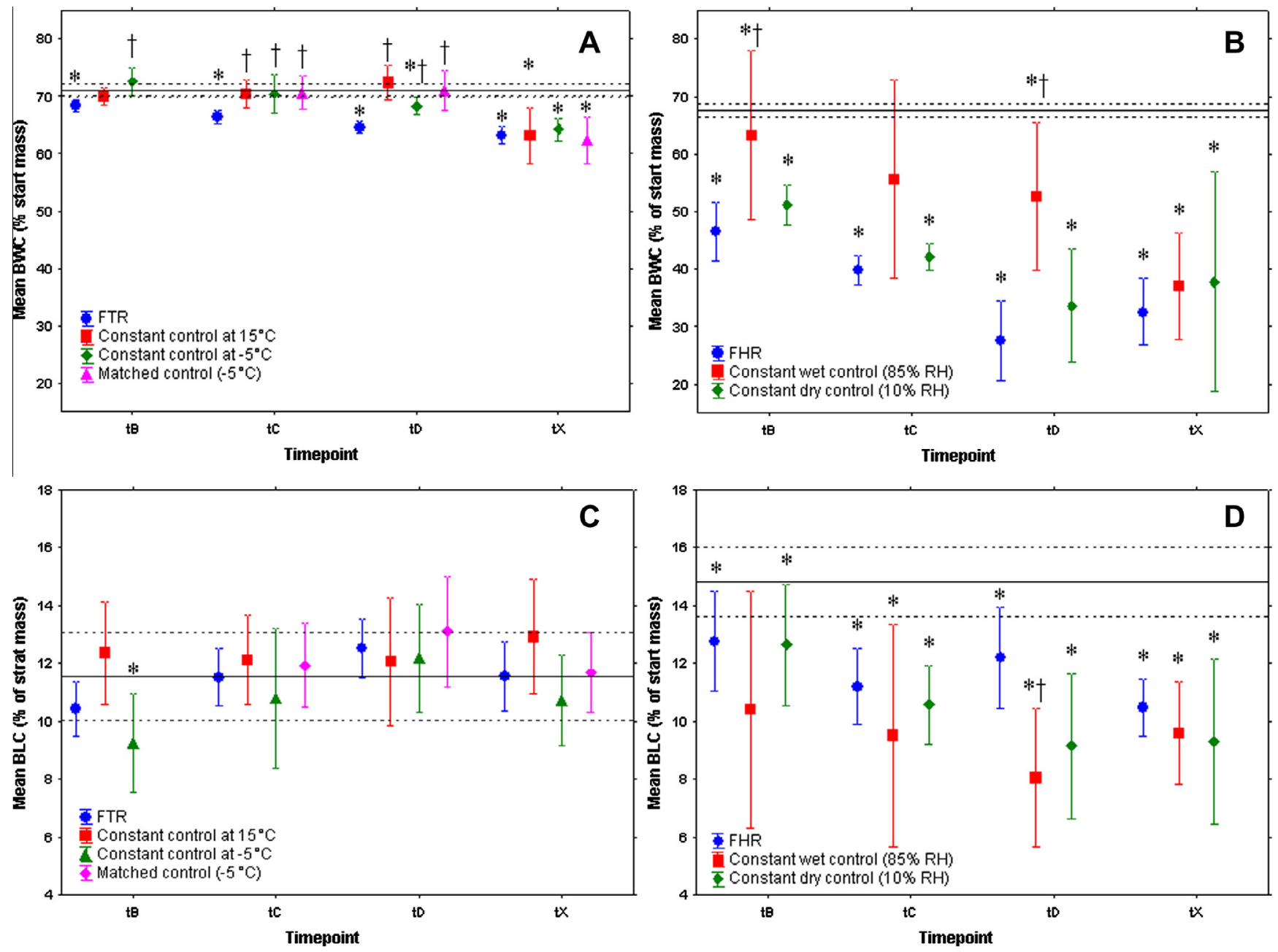

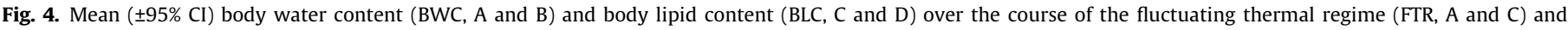

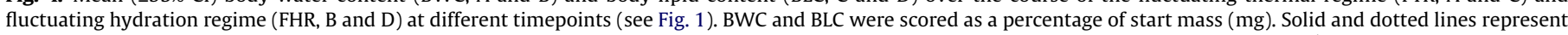

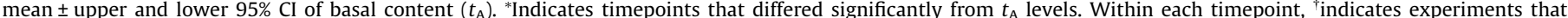

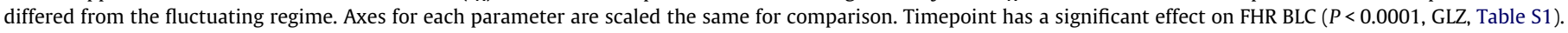

to return to levels comparable to $t_{\mathrm{B}}$ and $t_{\mathrm{C}}$ in larvae exposed to FHR. The HSP70 of larvae exposed to the constant wet control or dry control was significantly higher at $t_{\mathrm{D}}$ than the HSP70 of larvae exposed to the FHR. At $t_{\mathrm{X}}$ no differences in HSP70 between FHR and the controls were seen.

\subsection{Effects of FTR and FHR on larval survival, pupation, emergence}

Larval survival, pupation and emergence were significantly affected by experiment $\left(\chi^{2}=30.7, \mathrm{DF}=6, P<0.0001 ; \chi^{2}=29.7\right.$, $\mathrm{DF}=4, P<0.0001 ; \chi^{2}=29.8, \mathrm{DF}=4, P<0.0001$; Fig. 6$)$. Larvae exposed to FTR had $76.0 \%$ survival $(n=50)$, which is comparable to constant control $15{ }^{\circ} \mathrm{C}(90.0 \%, n=30)$, but significantly higher than larval survival after constant control $-5{ }^{\circ} \mathrm{C}(53.3 \%, n=30)$ and the time matched control $(48.3 \%, n=29)$. After the constant control $15{ }^{\circ} \mathrm{C}, 90.0 \%$ of larvae pupated and $85 \%$ emerged $(n=20)$, while larvae exposed to the constant control $-5{ }^{\circ} \mathrm{C}$ had the lowest pupation and emergence $(20.0 \%$ and $15 \%$ respectively, $n=20)$. Approximately $40 \%$ of larvae from both the FTR and matched control pupated ( $n=20$ each) with $33.3 \%$ emerging after FTR and $25 \%$ after the matched control. Out of 53 larvae exposed to FHR, $96.2 \%$ survived $(n=53)$, which was not significantly different to either constant RH control (wet control: $90.0 \%, n=10$; dry control: $77.8 \%$, $n=9 ; P>0.05)$. Pupation and emergence for larvae exposed to FHR were $90.9 \%$ and $78.8 \%$ respectively $(n=33$; Fig. 6$)$.

\section{Discussion}

While previous studies have clearly shown that FTR can increase cold survival in freeze intolerant insects generally (discussed by Koštál et al., 2007; e.g. Colinet et al., 2007a,b; Lalouette et al., 2011), mechanistic studies of the physiological effects of FTR are lacking for freeze intolerant Lepidoptera (but see Pullin and Bale, 1989; Churchill and Storey, 1989; Kim and Song, 2000), with most related studies investigating only freeze tolerant species (e.g. Sinclair and Chown, 2005) or only the effects of fluctuating temperature on development rates (e.g. Zalucki, 1982; Liu et al., 2002). Although the effects of FTR and FHR on mortality or life-history traits have been investigated simultaneously (e.g. fungal pathogenicity, Fargues and Luz, 2000) they do not measure overall physiological changes of the insect. Other studies examining these two stressors typically do not attempt to disentangle the fluctuating temperature and moisture stress, but instead change temperature and inadvertently relative humidity conditions vary (e.g. Pike et al., 2005). To our knowledge, our study is unique since it is the first to report on physiological changes of both repeated thermal and dehydration stress in the same freeze 

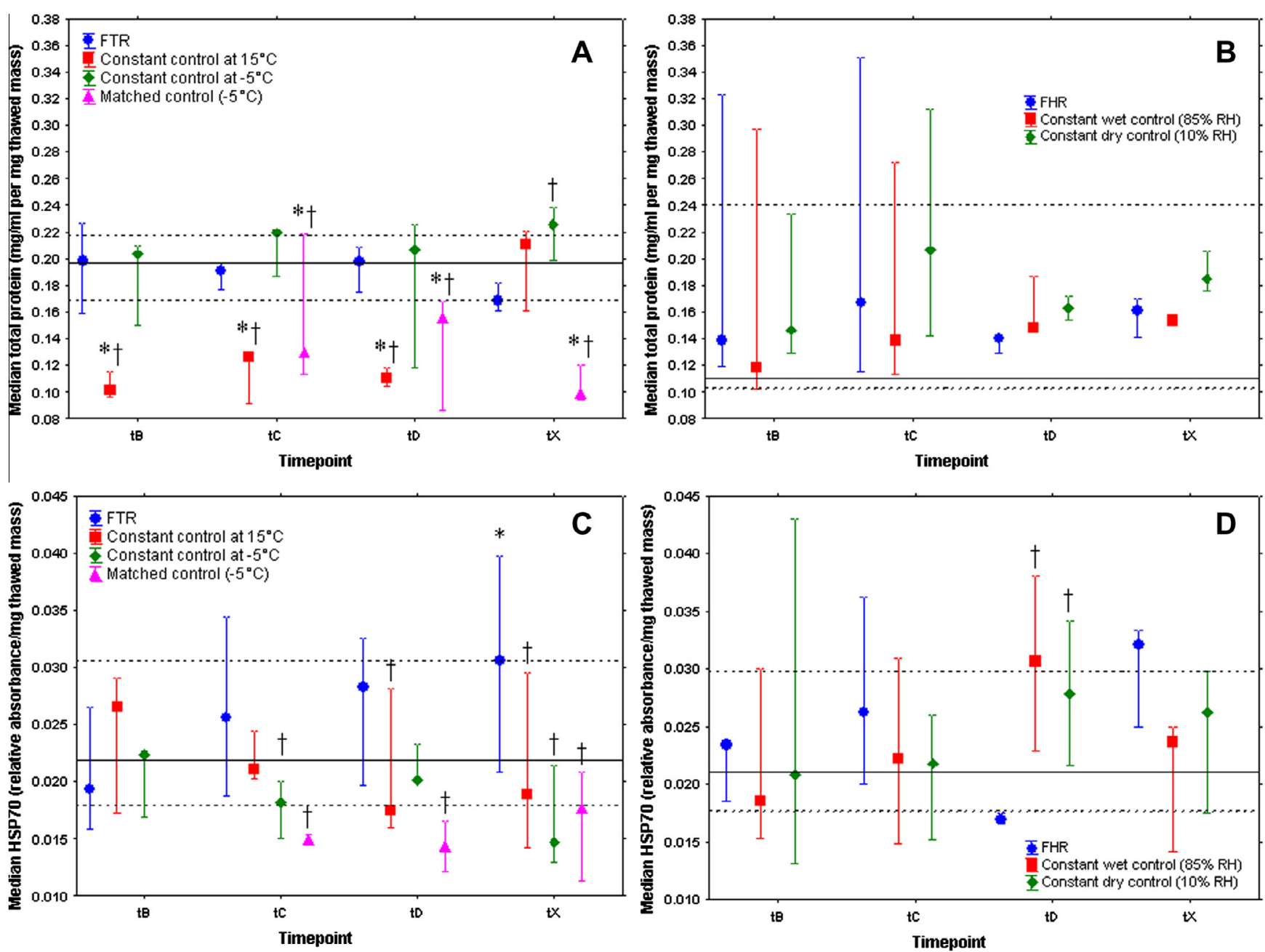

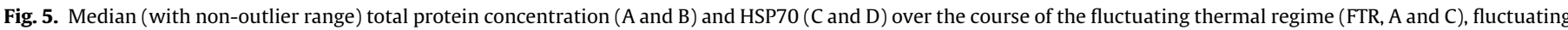

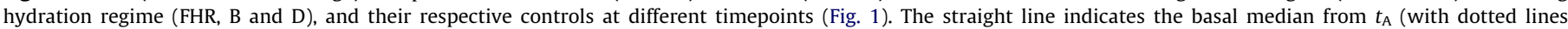

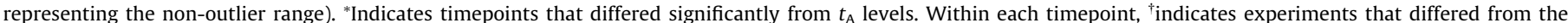

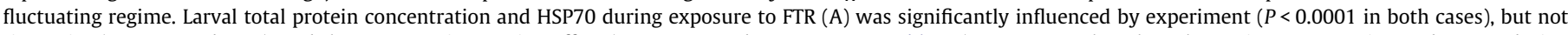

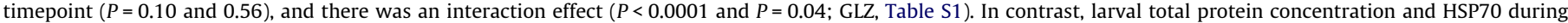
exposure to FHR (B) was not affected by experiment nor timepoint $(P>0.38$ in all cases) but there was an interaction effect for HSP70 $(P=0.01$, GLZ, Table S1).

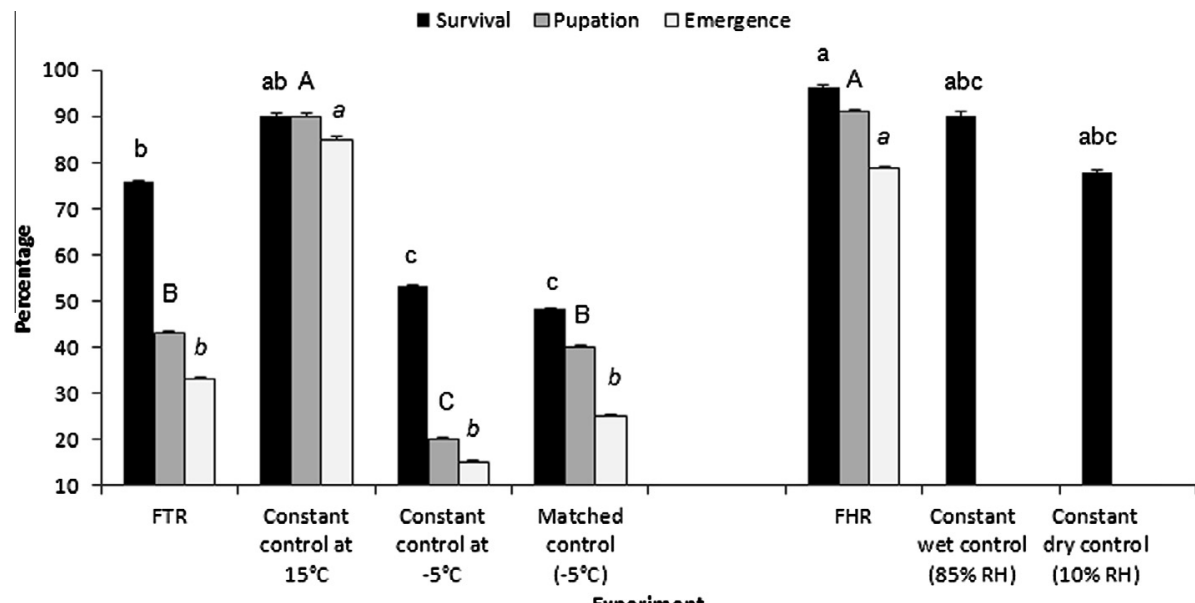

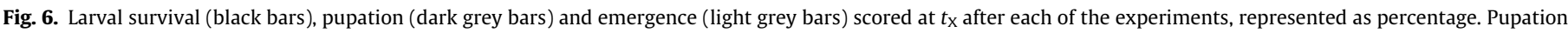

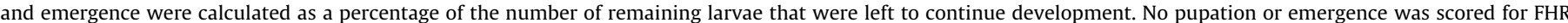

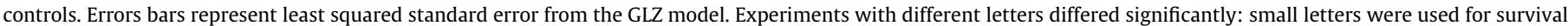
results (valid for comparison between FTR and FHR), capitals for pupation, and small italicised letters for emergence. 
intolerant species, as well as the first to record whole-animal metabolic rate during FHR and measure HSP70 in response to FHR. We found that both FTR and FHR did not result in high larval mortality and were comparable to constant controls at benign conditions (Fig. 6). Metabolic rate was regulated during both FTR and FHR. HSP70 levels increased during recovery from FTR $\left(t_{\mathrm{X}}\right)$, while during FHR, HSP70 decreased at the end of the 9 days cycling $\left(t_{\mathrm{D}}\right)$ before increasing again during recovery to be comparable to basal levels at $t_{\mathrm{x}}$. The survival results for larvae exposed to FTR, and metabolic rate, BWC, BLC and HSP70 for larvae exposed to either FTR or FHR, are in agreement with other studies published to date (e.g. Leopold et al., 1998; Tollarová-Borovanská et al., 2009; Teets et al., 2012). However, our result on survival for larvae exposed to FHR differs from our expectation that FHR would decrease larval survival, based on previous studies that have shown that FHR decreases overall fitness (e.g. Benoit et al., 2010; Teets et al., 2012).

Larval survival after FTR was comparable to larvae exposed to the constant control $15{ }^{\circ} \mathrm{C}$ while the pupation rates were significantly less after FTR than this control. This suggests that while the larvae are able to survive the thermal stress, they may not have sufficient energy reserves left to complete their life cycle. Alternatively, the increase in HSP70 needed to efficiently survive the FTR may be detrimental over longer time-periods (see Krebs and Feder, 1997,1998 ), the cold periods may affect cell cycle activities and induce an apoptotic response when returned to favourable growth conditions (Lalouette et al., 2010) or ATP homeostasis may not be regained after the cold exposure (Colinet 2011). This fitness consequence may be a common response to FTR, although generally few studies measure pupation and/or emergence rates in addition to larval survival. However, this long-term effect may be a similar fitness consequence to that of decreased fecundity in response to repeated cold exposures (e.g. Marshall and Sinclair, 2010; Renault, 2011; but see Basson et al., 2012). Exposure to FTR appears to be protective when compared to larvae exposed to the constant cold exposure at $-5{ }^{\circ} \mathrm{C}$ or the time-matched control, as the larvae exposed to FTR had a significantly higher rate of larval survival. This indicates that the FTR itself was not stressful or, alternatively, other mechanisms may be acting to reduce the impacts of the fluctuating thermal stress such as re-establishment of ion gradients (Koštál et al., 2007; MacMillan et al., 2012). For example, T. leucotreta have fructose, glucose and trehalose which likely act as cryoprotectants (Boardman et al., in preparation), and the concentrations present in larvae may be sufficient for coping with FTR at these timescales. The increase in larval survival after FTR (vs. constant control $-5{ }^{\circ} \mathrm{C}$ and time-matched control) is likely not a result of rapid cold-hardening, as no such responses have been found for $T$. leucotreta larvae (Boardman, unpublished) and limited plasticity of supercooling point and lower lethal temperature has been shown to date (Boardman et al., 2012). Based on the respirometry activity data which shows that larvae are able to resume active respiration during the benign recovery periods of FTR, larvae are capable of recovering and being active within a short period of time. This is supported by trial chill coma recovery assays which showed that all larvae were able to resume activity (walking) within ten minutes at $25^{\circ} \mathrm{C}$ after $2 \mathrm{~h}$ exposure at $-1{ }^{\circ} \mathrm{C}$ (Boardman, unpublished). The increase in $\dot{V} \mathrm{CO}_{2}$ during recovery periods of FTR, while not equal to, nor higher than the initial hold at $15^{\circ} \mathrm{C}$, may indicate that protective or repair processes are taking place. However, this rapid increase in metabolic rate with the return to warmer temperatures may result in oxidative damage and a subsequent need for antioxidants to counteract the cellular injury (Lalouette et al., 2011).

Larval BWC during exposure to FTR was significantly less than that of the larvae exposed to constant controls during the fluctuations $\left(t_{\mathrm{B}}-t_{\mathrm{D}}\right.$; Fig. $\left.4 \mathrm{~A}\right)$. Seven out of 11 individuals show excretion events in the $\mathrm{VH}_{2} \mathrm{O}$ trace during the 1st cycle of the FTR with no further excretion events evident after the start of the second cooling period. This correlates well with $\dot{V} \mathrm{H}_{2} \mathrm{O}$, with no significant changes occurring after this initial period (Fig. 3B). This may be due to larvae actively excreting water during the first cycle in preparation for the low temperature event, as well as the higher $\dot{V} \mathrm{CO}_{2}$ during recovery periods. Together, these results on larval BWC and $\dot{V} \mathrm{H}_{2} \mathrm{O}$ suggest that $T$. leucotreta are not prioritising water saving mechanisms at these FTR time/temperature scales, possibly in an attempt to limit ice nucleators in the gut (Lee, 2010; and see Boardman et al., 2012) or control ion homeostasis.

Exposure to FHR appear to have no survival benefits for larvae compared with the constant RH controls, although given that there are physiological changes it is perhaps reasonable to assume that they are actively responding to ensure survival under these conditions. Both previous studies on FHR have shown that it reduces metabolic reserves (Benoit et al., 2010; Teets et al., 2011). However, in our study $\dot{V} \mathrm{CO}_{2}$ is up-regulated during the first dehydration period only (i.e. first 2 days). For the rest of the FHR, no upregulation occurs (Fig. 3C) and metabolic rate remains comparable to that recorded in larvae at $25{ }^{\circ} \mathrm{C}$ (Boardman, unpublished). Therefore, the reduction in metabolic reserves found in previous studies may be due to the energy reserves being used to limit damage (e.g. by stabilizing membranes), and not due to increased metabolism. Alternatively, metabolic reserves such as glycogen may be broken down to compensate for dehydration stress. Likewise, the rapid dehydration used in our study may be too quick to allow the larvae to upregulate metabolic gene expression during the dehydration period (see Teets et al., 2013).

At $25{ }^{\circ} \mathrm{C}, \dot{V} \mathrm{H}_{2} \mathrm{O}$ is $0.84 \pm 0.18 \mathrm{mg} / \mathrm{h}$ with cuticular water loss (CWL) of $0.66 \pm 0.20 \mathrm{mg} / \mathrm{h}$ and respiratory water loss (RWL) of $0.18 \pm 0.04 \mathrm{mg} / \mathrm{h}$ (calculated from flow-through respirometry data following regression method described in Gibbs and Johnson, 2004). Therefore, at $25^{\circ} \mathrm{C}$ larvae would lose $20 \mathrm{mg} \mathrm{H}_{2} \mathrm{O}$ per day and should die within 3 days unless metabolic rate was down-regulated. Given that larvae only lose a total of $17.5 \mathrm{mg}$ during the FHR (Fig. S3), metabolic down-regulation most likely functions to limit RWL during the dehydration stress experienced under FHR, extending the time before the critical $50 \%$ body mass levels (equivalent to $20-35 \%$ BWC remaining) are reached. However, at best, reducing $\dot{V} \mathrm{H}_{2} \mathrm{O}$ would save a maximum of $4 \mathrm{mg} \mathrm{H}_{2} \mathrm{O}$ per day. This suggests that CWL would also need to be reduced to ensure the water-saving needed to survive. Therefore, there are most likely changes in cuticular permeability, possibly through variation in the amount or composition of hydrocarbons (reviewed in e.g. Gibbs and Rajpurohit, 2010; Chown et al., 2011), in T. leucotreta to counteract the dehydration stress.

To investigate this possibility further, total water loss (TWL), CWL and RWL for larvae were calculated for larvae during the final $15{ }^{\circ} \mathrm{C}$ hold of FTR (i.e. up to $t_{\mathrm{D}}$ ), and from the $16-20 \mathrm{~h}$ of day 8 (final day of dehydration) of FHR. Only larvae with periods of resting metabolic rate were used. The TWL, CWL and RWL $\left(\mathrm{mg} \mathrm{H}_{2} \mathrm{O} / \mathrm{h} /\right.$ mg mass) for larvae exposed to FTR are comparable with larvae recorded at a constant 15 or $25^{\circ} \mathrm{C}$ (Mann-Whitney $U$-test, $P>0.65$ ). However, the TWL and CWL of larvae were significantly reduced during exposure to FHR, in comparison to FTR $(Z=2.5, P=0.012)$, while RWL was not significantly different between FTR and FHR $(Z=1.9, P=0.06$; Fig. 7). The relative contributions of RWL to TWL (in \%) are not significantly different for both FTR and FHR $(P=0.7$; Fig. 7). The CWL in $T$. leucotreta larvae accounts for $80.1 \%$ of the variation in TWL during FTR, and 95.5\% during FHR (calculated using $r^{2}$ values of regressions, see Johnson and Gibbs, 2004). Therefore TWL decreases in FHR as a result of a decrease in CWL, further confirming the notion that the dehydration stress during FHR causes larvae to reduce CWL, probably in order to conserve water. 

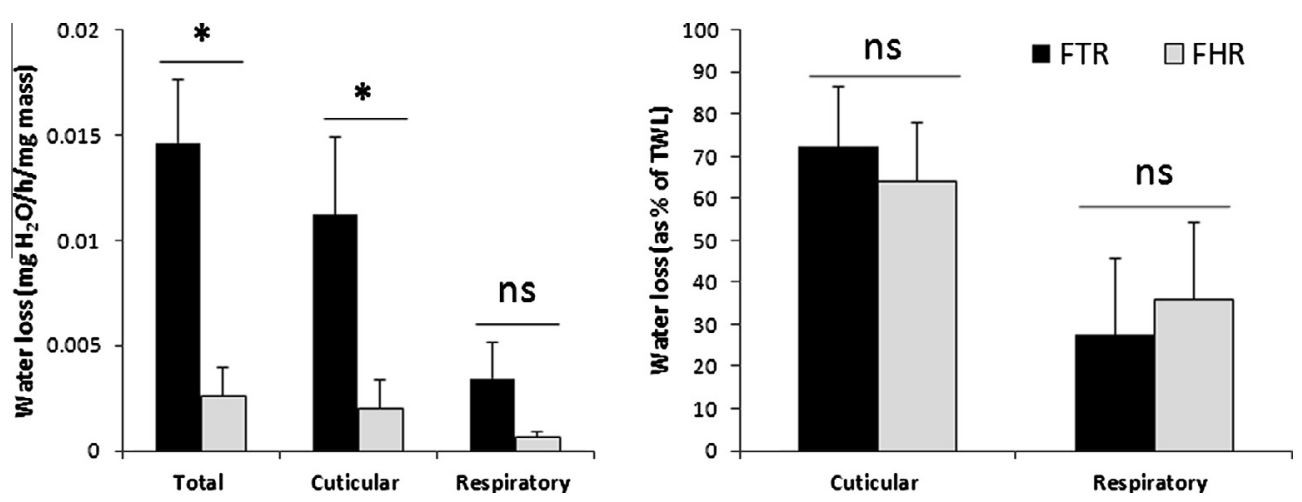

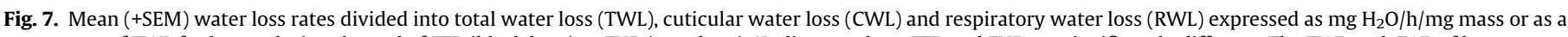

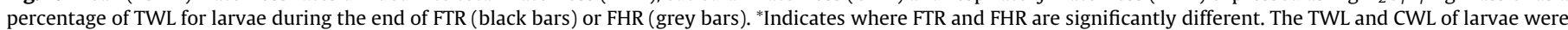

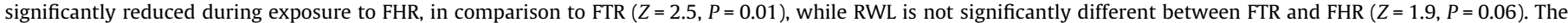
relative contributions of RWL to TWL (in \%) are the same for both FTR and FHR $(P=0.68)$.

The HSP70 of larvae exposed to FTR remains comparable to basal $\left(t_{\mathrm{A}}\right)$ HSP70 throughout the experiment, until $t_{\mathrm{X}}$ where it is significantly higher. HSP70 after FTR was significantly higher at $t_{\mathrm{X}}$ than all the other age and time-matched controls, perhaps explaining why these individuals exposed to FTR show high larval survival. The total protein concentration and HSP70 of the larvae exposed to the time-matched control at $t_{\mathrm{X}}$ is less than at $t_{\mathrm{A}}$, possibly indicating that the high mortality after this experiment may result from a lack of protein up-regulation and HSP70 during the first $24 \mathrm{~h}$ of recovery. The high variance in total protein concentration during the constant control at $-5^{\circ} \mathrm{C}$ and the time-matched control at $t_{\mathrm{C}}$ and $t_{\mathrm{D}}$ may be early signs of a disruption in protein homeostasis induced by environmental stress (Orlando and Guillette, 2001), and is supported by the high mortality after these FTR control experiments. The lack of HSP70 up-regulation during the exposure to FTR $\left(t_{\mathrm{B}}\right.$ to $\left.t_{\mathrm{D}}\right)$ may also occur because the 30 min recovery period at $15^{\circ} \mathrm{C}$ is not sufficient time to produce HSP70, even though $h s p 70$ mRNA may be up-regulated (Wang et al., 2006; Tollarová-Borovanská et al., 2009; Teets et al., 2011). Additionally, HSP70 may not be expressed in response to low temperature stress, and may instead only be up-regulated in response to rewarming stress (discussed in e.g. Nielsen et al., 2005). However, if this were the case in our experiments, we would have therefore expected an increase in HSP70 in all the FTR experiments from $t_{\mathrm{D}}$ to $t_{\mathrm{X}}$ when the larvae were moved to $25^{\circ} \mathrm{C}$ for recovery.

The HSP70 of larvae exposed to FHR drops during the final dehydration-recovery cycle, i.e. between $t_{C}$ and $t_{D}$, before increasing during the recovery period (HSP70 levels at $t_{\mathrm{X}}$ are comparable with $t_{\mathrm{A}}$, Fig. 5D). This suggests that HSP70 may be induced during favourable benign conditions of FHR to reduce rehydration stress (Hayward et al., 2004). However, given that the constant dry control $(10 \% \mathrm{RH})$ does not show the same increase between $t_{\mathrm{D}}$ and $t_{\mathrm{X}}$, the larvae exposed to FHR may need HSP70 to repair damage incurred during the fluctuations. The two controls remain comparable to HSP70 at $t_{\mathrm{A}}$ throughout the 10 day experiment, which suggests that $T$. leucotreta contain sufficient levels of basal HSP70 to counteract a significant amount of stress.

While the ecological relevance of using $10 \% \mathrm{RH}$ for dehydration and rapid shifts between $\mathrm{RH}$ conditions may be debatable, even at this low RH larvae of $T$. leucotreta are able to survive for at least 10 days, and those that pupate under these conditions are able to emerge as adults. Given this tolerance to dehydrating conditions, using more ecologically relevant $\mathrm{RH}$ fluctuations may not have elicited any changes in physiology before pupation occurred, and would thus not necessarily be more informative.

Although FTR and FHR experiments were performed over different timescales (i.e. FTR short-term, and FHR long-term) and used different stressors, it is nevertheless informative to make general comparisons of these two potential stressors (see Section 1). The 2 day FTR appears to be more stressful than the 10 day FHR as it results in higher mortality and lower pupation. The $\dot{V} \mathrm{CO}_{2}$ during FTR tightly follows the changes in temperature and after the $24 \mathrm{~h}$ recovery period is still significantly less than initial metabolic rate at $15{ }^{\circ} \mathrm{C}$. The $\dot{V} \mathrm{H}_{2} \mathrm{O}$ of larvae exposed to FTR decreases during the first two cycles and then stabilizes for the remainder of the experiment. The metabolic rate of larvae exposed to FHR is up-regulated during first dehydration period but for the remainder of the FHR no up-regulation occurs, and $\dot{V} \mathrm{H}_{2} \mathrm{O}$ remains unchanged. Exposure to short-term FTR increases HSP70 during the $24 \mathrm{~h}$ recovery, while HSP70 decreases during the third cycle of FHR and increases during the recovery period. Therefore, while both FTR and FHR rely on regulation of metabolic rate and HSP70, FHR is likely also dependent on water-saving mechanisms during dehydration stress.

\section{Conclusion}

This study has confirmed that exposure to FTR are protective when compared to constant low temperature exposures. The results indicate that survival stems from the warming periods allowing for stress repair and HSP70 up-regulation, and not because of less time spent at the low temperatures, as exposure to FTR results in significantly more larval survival than exposure to the matched control. However, our study shows that there may be potential long-term fitness consequences for larvae exposed to FTR, which warrants further investigation. This study also found that FHR appear neither protective nor damaging when compared to constant controls, although it was clear that the physiological responses to FHR included a decrease in CWL and changes in HSP70. For T. leucotreta specifically, it appears that fluctuating or repeated stressors are generally protective and are not more detrimental than constant stress conditions. Therefore, pest management and post-harvest sterilization strategies should perhaps avoid unnecessary fluctuations in stress conditions to avoid inadvertently inducing protective biochemical mechanisms. Future research into ion homeostasis and the role of cuticular permeability during fluctuating stress, as well as ecologically relevant daily fluctuations in T. leucotreta, would prove invaluable in contributing to understanding of the mechanisms induced by fluctuating stress.

\section{Acknowledgements}

The authors wish to thank Rob Stotter and XSIT for supplying larvae and Carlien Vorster for assistance with time-to-death 
experiment. This manuscript was improved by comments from Kate Mitchell, David Renault and an anonymous referee. This research was completed with partial financial support from Fruitgro Stellenbosch and Citrus Research International. L.B. was supported by a Harry Crossley bursary through Stellenbosch University, J.G.S. was supported by a Sapere Aude DFF-Starting Grant from The Danish Council for Independent Research|Natural Sciences and J.S.T. was supported by NRF Incentive Funding and Sub-Committee B (Stellenbosch University).

\section{Appendix A. Supplementary data}

Supplementary data associated with this article can be found, in the online version, at http://dx.doi.org/10.1016/j.jinsphys.2013. 05.005 .

\section{References}

Basson, C.H., Terblanche, J.S., 2011. Respirometry pattern transitions in three species of Glossina (Diptera, Glossinidae). Journal of Insect Physiology 57, 433443.

Basson, C.H., Nyamukondiwa, C., Terblanche, J.S., 2012. Fitness costs of rapid coldhardening in Ceratitis capitata. Evolution 66, 296-304.

Benoit, J.B., 2010. Water management by dormant insects: comparisons between dehydration resistance during summer aestivation and winter diapause. In Navas, C.A., Carvalho, J.E. (Eds.), Progress in Molecular and Subcellular Biology, Aestivation: Molecular and Physiological Aspects. Springer, Berlin, Germany, pp. 209-229.

Benoit, J.B., Patrick, K.R., Desai, K., Hardesty, J.J., Krause, T.B., Denlinger, D.L., 2010. Repeated bouts of dehydration deplete nutrient reserves and reduce eg production in the mosquito Culex pipiens. Journal of Experimental Biology 213 2763-2769.

Boardman, L., Grout, T.G., Terblanche, J.S., 2012. False codling moth Thaumatotibia leucotreta (Lepidoptera, Tortricidae) larvae are chill-susceptible. Insect Science $19,315-328$

Chown, S.L., Terblanche, J.S., 2007. Physiological diversity in insects: ecological and evolutionary contexts. Advances in Insect Physiology 33, 50-152.

Chown, S.L., Sørensen, J.G., Terblanche, J.S., 2011. Water loss in insects: an environmental change perspective. Journal of Insect Physiology 57, 1070-1084.

Churchill, T.A., Storey, K.B., 1989. Metabolic consequences of rapid cycles of temperature change for freeze-avoiding vs freeze-tolerant insects. Journal of Insect Physiology 35, 579-585.

Clark, M.S., Worland, M.R., 2008. How insects survive the cold: molecula mechanisms - a review. Journal of Comparative Physiology B 178, 917-933.

Clusella-Trullas S., Boardman L., Faulkner K.T., Peck, L.S. and Chown S.L., Effects of temperature on heat-shock responses and survival of two species of marine invertebrates from sub-Antarctic Marion Island, Antarctic Science, in press.

Colinet, H., 2011. Disruption of ATP homeostasis during chronic cold stress and recovery in the chill susceptible beetle (Alphitobius diaperinus). Comparative Biochemistry and Physiology A 160, 63-67.

Colinet, H., Hoffman, A.A., 2012. Comparing phenotypic effects and molecular correlates of developmental, gradual and rapid cold acclimation responses in Drosophila melanogaster. Functional Ecology 26, 84-93.

Colinet, H., Nguyen, T.T.A., Cloutier, C., Michaud, D., Hance, T., 2007a. Proteomic profiling of a parasitic wasp exposed to constant and fluctuating cold exposure. Insect Biochemistry and Molecular Biology 37, 1177-1188.

Colinet, H., Hance, T., Vernon, P., Bouchereau, A., Renault, D., 2007b. Does fluctuating thermal regime trigger free amino acid production in the parasitic wasp Aphidius colemani (Hymenoptera: Aphidiinae)? Comparative Biochemistry and Physiology A 147, 484-492.

Dollo, V.H., Yi, S.-X., Lee, R.E., 2010. High temperature pulses decreases indirect chilling injury and elevate ATP levels in the flesh fly, Sarcophaga crassipalpis. Cryobiology 60, 351-353.

Fargues, J., Luz, C., 2000. Effects of fluctuating moisture and temperature regimes on the infection potential of Beauveria bassiana for Rhodnius prolixus. Journal of Invertebrate Pathology 75, 202-211.

Folguera, G., Bastías, D.A., Caers, J., Rojas, J.M., Piulachs, M.-D., Bellés, X., Bozinovic, F., 2011. An experimental test of the role of environmental temperature variability on ectotherm molecular, physiological and life-history traits: implications for global warming. Comparative Biochemistry and Physiology A $159,242-246$

Gibbs, A.G., Johnson, R.A., 2004. The role of discontinuous gas exchange in insects: the chthonic hypothesis does not hold water. Journal of Experimental Biology 207, 3477-3482

Gibbs, A.G., Rajpurohit, S., 2010. Cuticular lipids and water balance. In: Blomquist G.J., Bagneres, A.G. (Eds.), Insect Hydrocarbons: Biology, Biochemistry, and Chemical Ecology. Cambridge University Press, Cambridge, UK, pp. 100-120.

Goller, F., Esch, H., 1990. Comparative study of chill-coma temperatures and muscle potentials in insect flight muscles. Journal of Experimental Biology 150, 221 231.
Hadley, N.F., 1994. Ventilatory patterns and respiratory transpiration in adult terrestrial insects. Physiological Zoology 67, 175-189.

Hagstrum, D.W., Milliken, G.A., 1991. Modelling differences in insect developmental times between constant and fluctuating temperatures. Annals of the Entomological Society of America 84, 369-379.

Hayward, S.L., Rinehart, J.P., Denlinger, D.L., 2004. Desiccation and rehydration elicit distinct heat shock protein transcript responses in flesh fly pupae. Journal of Experimental Biology 207, 963-971.

Hochachka, P.W., Somero, G.N., 2002. Biochemical Adaptation: Mechanisms And Process In Physiological Evolution. Oxford University Press, Oxford, New York, USA.

Hosler, J.S., Burns, J.E., Esch, H.E., 2000. Flight muscle resting potential and speciesspecific differences in chill-coma. Journal of Insect Physiology 46, 621-627.

Huey, R.B., Bennett, A.F., 1990. Physiological adjustments to fluctuating thermal environments: an ecological and evolutionary perspective. In: Morimoto, R., Tessieres, A., Georgopoulous, C. (Eds.), Stress Proteins in Biology and Medicine. Cold Spring Harbor Laboratory Press, Cold Spring Harbor, New York, USA, pp. 37-59.

Johnson, R.A., Gibbs, A.G., 2004. Effect of mating stage on water balance, cuticular hydrocarbons and metabolism in the desert harvester ant, Pogonomyrmex barbatus. Journal of Insect Physiology 50, 943-953.

Kashmeery, A.M.S., Bowler, K., 1977. A study or recovery from heat injury in the blowfly (Calliphora erythrocephala) using split-dose experiments. Journal of Thermal Biology 2, 183-184.

Karl, I., Sørensen, J.G., Loeschcke, V., Fischer, K., 2009. HSP70 expression in the Copper butterfly Lycaena tityrus across altitudes and temperatures. Journal of Evolutionary Biology 22, 172-178.

Kellermann, V., Loeschcke, V., Hoffmann, A.A., Kristensen, T.N., Fløjgaard, C., David, J.R., Svenning, J.-C., Overgaard, J., 2012. Phylogenetic constraints in key functional traits behind species' climate niches: patterns of desiccation and cold resistance across 95 Drosophila species. Evolution 66, 3377-3389.

Kim, Y., Song, W., 2000. Effect of thermoperiod and photoperiod on cold tolerance of Spodoptera exigua (Lepidoptera: Noctuidae). Environmental Entomology 29, 868-873.

Koštál, V., Renault, D., Mehrabianová, A., Bastl, J., 2007. Insect cold tolerance and repair of chill-injury at fluctuating thermal regimes: role of ion homeostasis. Comparative Biochemistry and Physiology A 147, 231-238.

Krebs, R.A., Feder, M.E., 1997. Deleterious consequences of Hsp70 overexpression in Drosophila melanogaster larvae. Cell Stress \& Chaperones 2, 60-71.

Krebs, R.A., Feder, M.E., 1998. Hsp70 and larval thermotolerance in Drosophila melanogaster: how much is enough and when is more too much? Journal of Insect Physiology 44, 1091-1101.

Lalouette, L., Koštál, V., Colinet, H., Gagneul, D., Renault, D., 2007. Cold exposure and associated changes in adult tropical beetles exposed to fluctuating thermal regimes. FEBS Journal 274, 1759-1767.

Lalouette, L., Renault, D., Ravaux, J., Siaussat, D., 2010. Effects of cold-exposure and subsequent recovery on cellular proliferation with influence of 20hydroxyecdysone in a lepidopteran cell line (IAL-PID2). Comparative Biochemistry and Physiology A 155, 407-414.

Lalouette, L., Williams, C.M., Hervant, F., Sinclair, B.J., Renault, D., 2011. Metabolic rate and oxidative stress in insects exposed to low temperature thermal fluctuations. Comparative Biochemistry and Physiology A 158, 229-234.

Lee, R.E., 2010. A primer on insect cold tolerance. In: Denlinger, D.L., Lee, R.E. (Eds.), Low Temperature Biology of Insects. Cambridge University Press, Cambridge, UK, pp. 3-34.

Leopold, R.A., Rojas, R.R., Atkinson, P.W., 1998. Post pupariation cold storage of three species of flies: increasing chilling tolerance by acclimation and recurrent recovery periods. Cryobiology 36, 213-224.

Lighton, J.R.B., 2008. Measuring metabolic rates: a manual for Scientists. Oxford University Press, New York, USA

Liu, S.-S., Chen, F.-Z., Zalucki, M.P., 2002. Development and survival of the diamondback moth (Lepidoptera: Plutellidae) at constant and alternating temperatures. Environmental Entomology 31, 221-231.

MacMillan, H.A., Sinclair, B.J., 2011. Mechanisms underlying insect chill-coma. Journal of Insect Physiology 57, 12-20.

MacMillan, H.A., Williams, C.M., Staples, J.F., Sinclair, B.J., 2012. Reestablishment of ion homeostasis during chill-coma recovery in the cricket Gryllus pennsylvanicus. Proceedings of the National Academy of Sciences of the United States of America 109, 20750-20755.

Marshall, K.E., Sinclair, B.J., 2010. Repeated stress exposure results in a survivalreproduction trade-off in Drosophila melanogaster. Proceedings of the Royal Society of London B 277, 963-969.

Marshall, K.E., Sinclair, B.J., 2012. The impacts of repeated cold exposure on insects. Journal of Experimental Biology 215, 1607-1613.

Nedved, O., Lavy, D., Verhoef, H.A., 1998. Modelling the time-temperature relationship in cold injury and effect of high-temperature interruptions on survival in a chill-sensitive collembolan. Functional Ecology 12, 816-824.

Niehaus, A.C., Angiletta, M.J., Sears, M.W., Franklin, C.E., Wilson, R.S., 2012. Predicting the physiological performance of ectotherms in fluctuating thermal environments. Journal of Experimental Biology 215, 694-701.

Nielsen, M.M., Overgaard, J., Sørensen, J.G., Holmstrup, M., Justesen, J., Loeschcke, V., 2005. Role of HSF activation for resistance to heat, cold and high-temperature knock-down. Journal of Insect Physiology 51, 1320-1329.

Orlando, E.F., Guillette, L.J., 2001. A re-examination of variation associated with environmentally stressed organisms. Human Reproduction Update 7, 265-272. 
Pike, A.J., Cunningham, M.J., Lester, P.J., 2005. Development of Dermatophagoides pteronyssinus (Acari: Pyroglyphidae) at constant and simultaneously fluctuating temperature and humidity conditions. Journal of Medical Entomology 42, 266269.

Pullin, A.S., Bale, J.S., 1989. Effects of low temperature on diapausing Aglais urticae and Inachis io (Lepidoptera: Nymphalidae): cold hardiness and overwintering survival. Journal of Insect Physiology 35, 277-281.

Reed, W., 1974. The false codling moth, Cryptophlebia leucotreta (Meyrick) (Lepidoptera: Olethreutidae) as a pest of cotton in Uganda. Cotton Growing Review 51, 213-225.

Renault, D., Nedved, O., Hervant, F., Vernon, P., 2004. The importance of fluctuating thermal regimes for repairing chill injuries in the tropical beetle Alphitobius diaperinus (Coleoptera: Tenebrionidae) during exposure to low temperature. Physiological Entomology 29, 139-145.

Renault, D., 2011. Long-term after-effects of cold exposure in adult Alphitobius diaperinus (Tenebrionidae): the need to link survival ability with subsequent reproductive success. Ecological Entomology 36, 36-42.

Richards, A.G., Suanraksa, S., 1962. Energy expenditure during embryonic development under constant versus variable temperatures (Oncopeltus fasciatus (Dallas)). Entomologia Experimentalis et Applicata 5, 167-178.

Ring, R.A., Danks, H.V., 1994. Desiccation and cryoprotection: overlapping adaptations. Cryoletters 15, 181-190.

Ruel, J.J., Ayres, M.P., 1999. Jensen's inequality predicts effects of environmental variation. Trends in Ecological Evolution 14, 361-366.

Schimpf, N.G., Matthews, P.G.D., Wilson, R.S., White, C.R., 2009. Cockroaches breathe discontinuously to reduce respiratory water loss. Journal of Experimental Biology 212, 2773-2780.

Sinclair, B.J., Chown, S.L., 2005. Deleterious effects of repeated cold exposure in a freeze-tolerant sub-Antartic caterpillar. Journal of Experimental Biology 208, 869-879.

Sørensen, J.G., Loeschcke, V., Kristensen, T.N., 2013. Cellular damage as induced by high temperature on rate of temperature change-investigating consequences of ramping rates on molecular and organismal phenotypes in Drosophila melanogaster Meigen 1830. Journal of Experimental Biology 216, 809-814.

Stevens, M.M., Jackson, S., Bester, S.A., Terblanche, J.S., Chown, S.L., 2010. Oxygen limitation and thermal tolerance in two terrestrial arthropod species. Journal of Experimental Biology 213, 2209-2218.

Storey, K.B., Storey, J.M., 2004. Metabolic rate depression in animals: transcriptional and translational controls. Biological Reviews 79, 207-233.

Storey, K.B., Storey, J.M., 2012. Insect cold hardiness: metabolic, gene, and protein adaptation. Canadian Journal of Zoology 90, 456-475.

Teets, N.M., Kawarasaki, Y., Lee Jr., R.E., Denlinger, D.L., 2011. Survival and energetic costs of repeated cold exposure in the Antarctic midge, Belgica Antarctica: a comparison between frozen and supercooled larvae. Journal of Experimental Biology 214, 806-814.
Teets, N.M., Kawarasaki, Y., Lee Jr., R.E., Denlinger, D.L., 2012. Energetic consequences of repeated and prolonged dehydration in the Antarctic midge, Belgica Antarctica. Journal of Insect Physiology 58, 498-505.

Teets, N.M., Kawarasaki, Y., Lee Jr., R.E., Denlinger, D.L., 2013. Expression of genes involved in energy mobilization and osmoprotectant synthesis during thermal and dehydration stress in the Antarctic midge, Belgica antarctica. Journal of Comparative Physiology B 183, 189-201.

Terblanche, J.S., Nyamukondiwa, C., Kleynhans, E., 2010a. Thermal variability alters climatic stress resistance and plastic responses in a globally invasive pest, the Mediterranean fruit fly (Ceratitis capitata). Entomologia Experimentalis et Applicata 137, 304-315.

Terblanche, J.S., Clusella-Trullas, S., Chown, S.L., 2010b. Phenotypic plasticity of gas exchange pattern and water loss in Scarabaeus spretus (Coleoptera: Scarabaeidae): deconstructing the basis for metabolic rate variation. Journal of Experimental Biology 213, 2940-2949.

Tollarová-Borovanská, M., Lalouette, L., Koštál, V., 2009. Insect cold tolerance and repair of chill-injury at fluctuating thermal regimes: role of $70 \mathrm{kDa}$ heat shock protein expression. CryoLetters 30, 312-319.

Verberk, W.C.E.P., Calosi, P., 2012. Oxygen limits heat tolerance and drives heat hardening in the aquatic nymphs of the gill breathing damselfly Calopteryx virgo (Linnaeus, 1758). Journal of Thermal Biology 37, 224-229.

Wang, H.-S., Zhou, C.-S., Gho, W., Kang, L., 2006. Thermoperiodic acclimations enhance cold hardiness of the eggs of the migratory locust. Cryobiology 53, 206-217.

White, C.R., Portugal, S.J., Martin, G.R., Butler, P.J., 2006. Respirometry: anhydrous drierite equilibrates with carbon dioxide and increases washout times. Physiological and Biochemical Zoology 79, 977-980.

Whitman, D.W., Agrawal, A.A., 2009. What is phenotypic plasticity and why is it important? In: Whitman, D.W., Ananthakrishnan, T.N. (Eds.), Phenotypic Plasticity of Insects. Mechanisms and Consequences. Science Publishers, Enfield, NH, USA, pp. 1-63.

Woods, H.A., Smith, J.N., 2010. Universal model for water costs of gas exchange by animals and plants. Proceedings of the National Academy of Sciences of the United States of America 107, 8469-8474.

Worner, S.P., 1992. Performance of phenological models under variable temperature regimes: consequences of the Kaufmann or rate summation effect. Environmental Entomology 21, 689-699.

Yocum, G.D., Greenlee, K.J., Rinehart, J.P., Bennett, M.M., Kemp, W.P., 2011. Cyclic $\mathrm{CO}_{2}$ emissions during the high temperature pulse of fluctuating thermal regime in eye-pigmented pupae of Megachile rotundata. Comparative Biochemistry and Physiology A 160, 480-485.

Zalucki, M.P., 1982. Temperature and rate of development in Danaus plexippus L. and D. chrysippus L. (Lepidoptera: Nymphalidae). Journal of the Australian Entomological Society 21, 241-246. 